\title{
Chapter 2 \\ Genetic Resources of Crop Wild Relatives: A Canadian Perspective
}

\author{
Axel Diederichsen and Michael P. Schellenberg
}

\begin{abstract}
Canada is home to about 5087 species of higher plants of which $25 \%$ were introduced to Canada either deliberately or by accident. The richness of botanical species is highest in the southern, more densely settled parts of the country. About 364 native Canadian species have direct or potential use in crop development for various usages with particular emphasis on use for berries and as forages. The use of more than 600 plant species by indigenous people for food, medicine, or spiritual reasons is documented, and they practiced agriculture prior to colonization by Europeans with cultivations of corn, garden bean, squash, sunflower, and tobacco. Only a few native species are crop wild relatives of major agricultural crops such as 14 species of the genus Helianthus L., which are related to cultivated sunflower. Taxonomists have made major contributions to recognize the potential of the Canadian flora from a utilitarian aspect. Plant breeding in Canada has been done by the government of Canada, by universities, and, more recently, also by the private sector. The focus has been on major crops, while the activities in forages and minor crops have decreased. Canada maintains a national genebank for ex situ conservation (Plant Gene Resources of Canada). More activities to enhance the complementarity between in situ and ex situ conservation should be undertaken in Canada. The potential of native rangeland plants or weeds as genetic resources is emphasized. The "integrating genebank" is suggested as an ambitious concept. In order to maintain the future options Canadian biodiversity holds for enhancing life and livelihoods, a national strategy is required.
\end{abstract}

Keywords Native Canadian plant species · Ex situ conservation · In situ conservation · Weeds · Indigenous food plants · Plant genetic resources · Taxonomy · Diversification of agriculture $\cdot$ Native rangeland plants $\cdot$ Nutrition $\cdot$ National biodiversity strategy $\cdot$ Invasive species $\cdot$ Wild fruits

\footnotetext{
A. Diederichsen $(\bowtie)$

Agriculture and Agri-Food Canada, Plant Gene Resources of Canada, Saskatoon, SK, Canada e-mail: axel.diederichsen@agr.gc.ca

M. P. Schellenberg

Agriculture and Agri-Food Canada, Swift Current Research and Development Centre,

Swift Current, SK, Canada

e-mail: mike.schellenberg@agr.gc.ca
}

S. L. Greene et al. (eds.), North American Crop Wild Relatives, Volume 1, https://doi.org/10.1007/978-3-319-95101-0_2 


\subsection{Broad Overview}

Canada's land area amounts to $9,984,670 \mathrm{~km}^{2}$ which is about $7 \%$ of the terrestrial surface of the globe. The longest east-west distance is about $5514 \mathrm{~km}$, and the longest north-south distance is $4634 \mathrm{~km}$. The arctic tundra in the north is vast, and the boreal forest stretches as a belt from the Pacific to the Atlantic coast. These two vegetation zones cover two-thirds of the country and are very sparsely settled. Canada has 15 terrestrial ecozones that are subdivided into 53 ecoprovinces with 194 ecoregions. Figure 2.1 shows the large forested band that covers more than $40 \%$ of Canada's land surface and includes, from west to east, the Pacific Maritime, Boreal Cordillera, Montane Cordillera, Boreal Plains, Boreal Shield, Hudson Plains, and Atlantic Maritime ecozones.

Politically, Canada is divided into ten provinces and three territories. Only the southern parts of the country are densely settled and conducive for agricultural plant

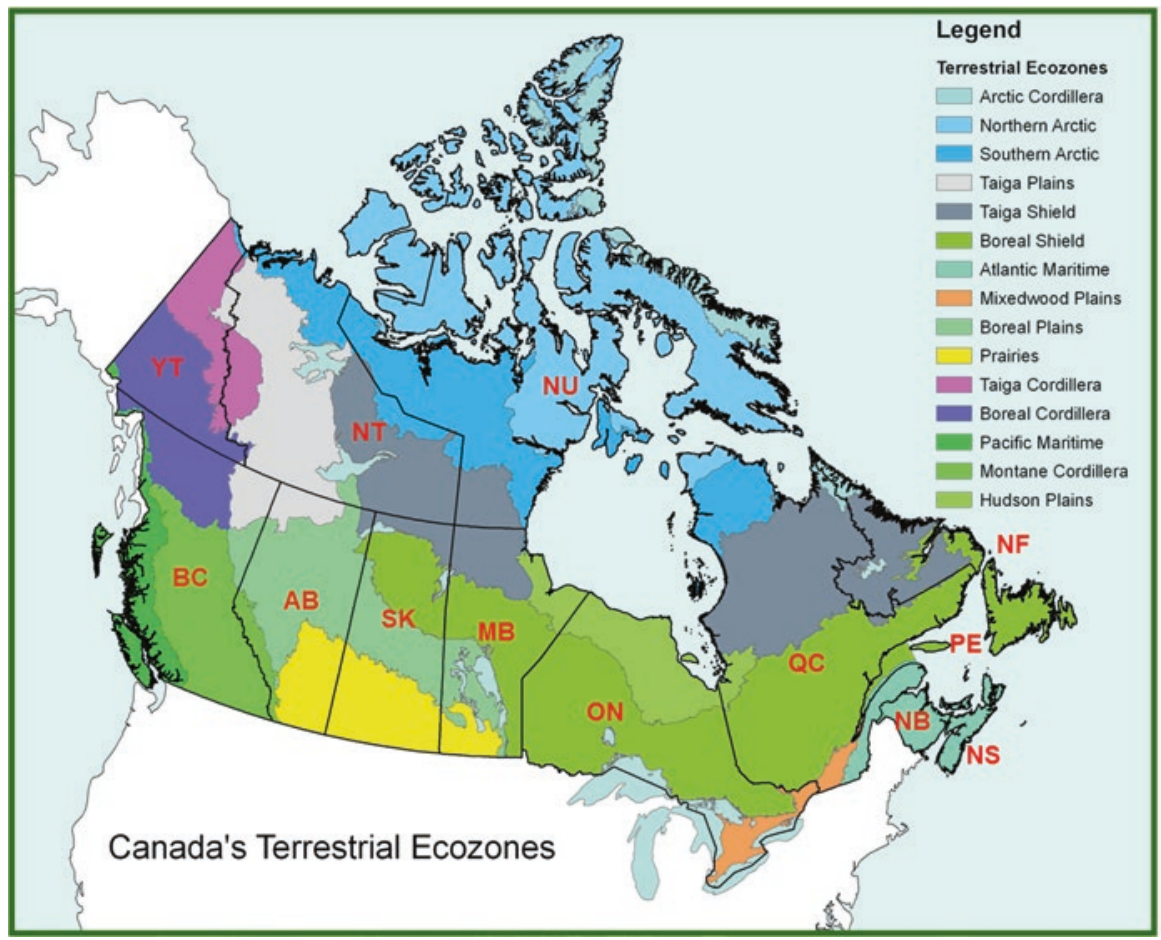

Fig. 2.1 Canada's terrestrial ecozones with borders of provinces and territories indicated (Natural Resources Canada 2017). Abbreviations: AB Alberta, BC British Columbia, MB Manitoba, NB New Brunswick, NF Newfoundland and Labrador, NS Nova Scotia, NT Northwest Territories, NU Nunavut (territory), ON Ontario, PE Prince Edward Island, QC Québec, SK Saskatchewan, YT Yukon (territory) 


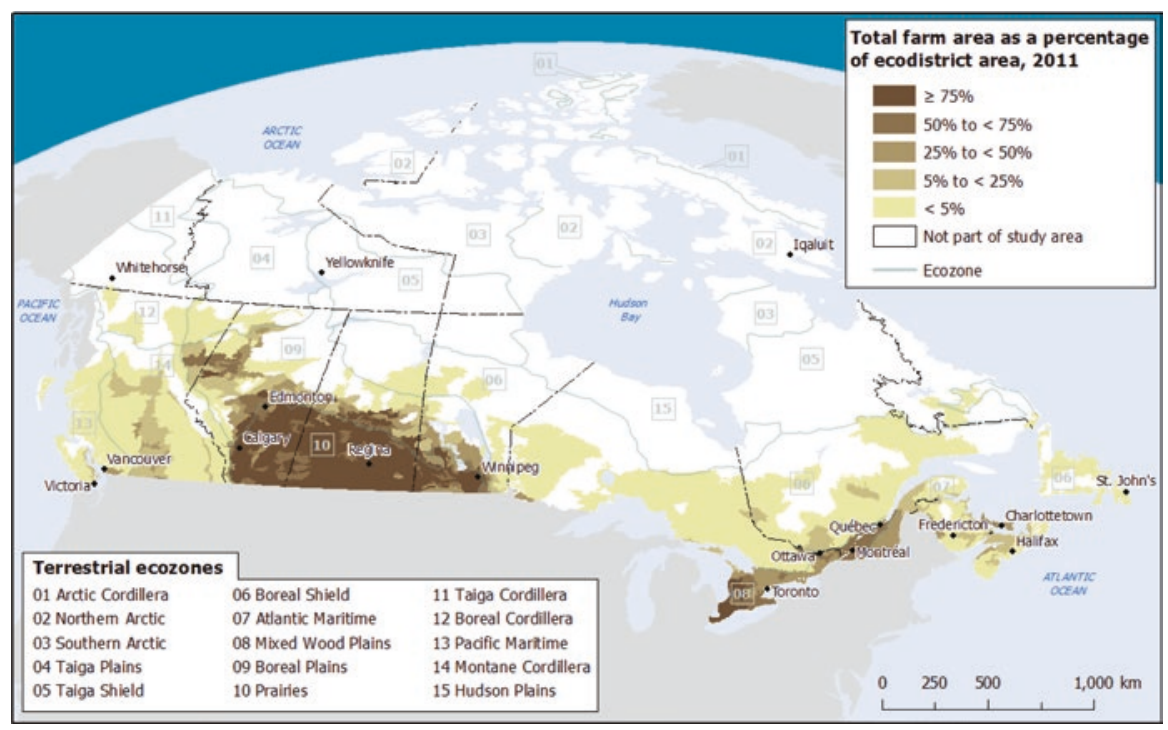

Fig. 2.2 Farmland distribution in Canada. (Statistics Canada 2014)

production. These areas also have more diversified vegetation than the vast northern regions. For agriculture, the prairies of Western Canada are most important (Fig. 2.2). Canada was nearly completely covered by inland ice during the last ice age. As a result, there are only a few pockets with species of preglacial origin, and the number of species endemic to Canada is low.

The number of species of higher plants reported for Canada is 5087 (Candian Food Inspection Agency 2008). Of these, 10 plant species are categorized as being endangered, 47 as threatened, and 46 as being of special concern (COSEWIC 2017). It is remarkable that 1229 vascular plant species, which amounts to about $25 \%$ of the total Canadian flora, consist of alien species that were introduced to Canada (Canadian Food Inspection Agency 2008). Of the alien species, 483 are weedy or invasive, and more than half of these were introduced deliberately as crops, as ornamentals, or for other usages. Darbyshire (2003) provided an inventory of Canadian weeds listing 872 species in total, including the native weed species. Due to the size and ecological diversity of the country, 316 native Canadian species are considered introduced in some parts of the country, and of these 69 are categorized as invasive. The degree of impact anthropogenic activity has had on the Canadian flora is tremendous. In the agricultural areas of the western provinces of Alberta, Saskatchewan, and Manitoba, there are only relicts of native habitats left. Figure 2.3 shows that the number of invasive species is particularly high in the more densely settled areas in the southern parts. Although alien species can be invasive and therewith threaten the native flora, it is important to remember that many alien species are crops and crop wild relatives or have potential for use. Trade and colonization have brought many 


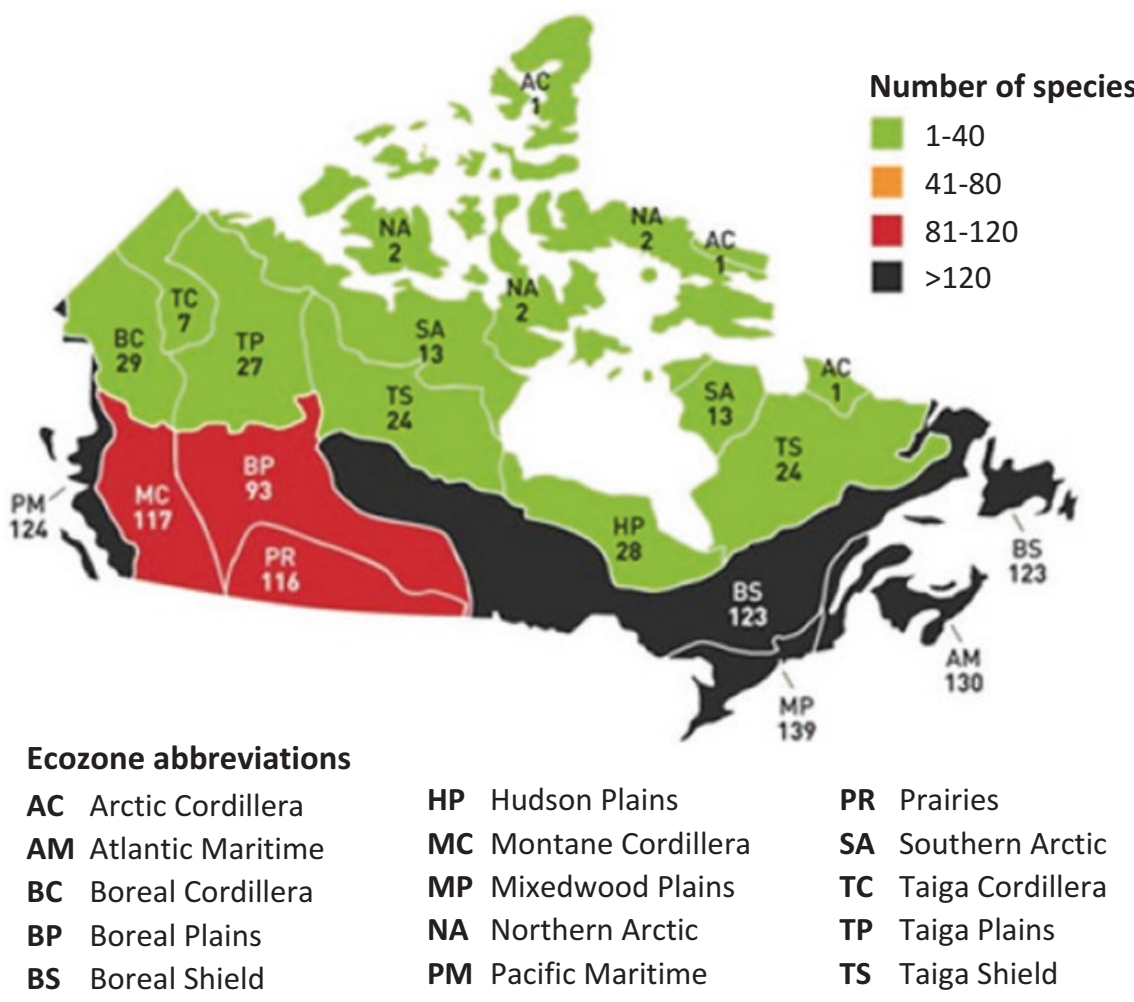

Fig. 2.3 Number of invasive alien plant species in Canada by ecozone. Based on 162 species for which distribution maps were available. (Canadian Food Inspection Agency 2008)

species from Europe, China, and Japan. Figure 2.3 is an approximation, as many of the less populated areas in Canada have no detailed floristic inventories. An excellent and steadily updated checklist for Canadian vascular plants with distribution maps is available on the Internet (Brouillet et al. 2010).

Davidson (1995) reported that 364 native Canadian species have direct or potential use in crop development or breeding programs. He grouped these plant genetic resources into the following categories: forage and turf grasses (138 species); fruit crops (111 species); cereals, oilseeds, and other field crops (18 species); special and minor crops (86 species); and nut crops (11 species). In addition, Davidson (1995) listed 137 genera of native landscape plants and concluded that the potential of these remains untapped. That such a high number of native Canadian taxa are plant genetic resources of economic significance is striking, as Canada is not located in one of the centers of diversity of cultivated plants first pointed out by Vavilov (1926). Nearly all important crops presently grown in Canada trace their evolutionary origin to other parts of the world. 
The agriculture of the indigenous people of Canada that existed long before immigration of Europeans cultivated a few plants, namely, maize (Zea mays L.), garden bean (Phaseolus vulgaris L.), squash (Cucurbita pepo L.), Jerusalem artichoke (Helianthus tuberosus L.), tobacco (Nicotiana rustica L.), and possibly sunflower (Helianthus annuus L.). These plants also have their evolutionary origin outside of Canada in the more southern parts of the North American continent. Relict cultivation of these plants using autochthonous (native) genetic resources may still exist in the province of Québec (Gros-Louis and Gariépy 2013). Some of the diversity of these crops has been preserved due to conservation in the national genebanks of Canada and the United States (PGRC 2016). Wildrice (Zizania palustris L., Z. aquatica L.) is a special case. It has been used by indigenous people long before colonization, but it is not a cultivated plant species as such, although some habitat management may justify it being considered partly domesticated, a status it may share with Helianthus tuberosus. There is insufficient knowledge about the interactions between plants and man prior to immigration by Europeans. Kuhnlein and Turner (1991) presented a monograph on this subject. Exploring these questions with focus on livelihoods and future directions recently gained some momentum (Agriculture and Agri-Food Canada 2017) and is also emphasized more on the international scale (Heywood 1999a).

None of the crop wild relatives found in Canada belong to the primary genepool of a major agricultural field crop. Regarding the secondary and tertiary genepool for sunflower breeding, there are 14 Helianthus species in Canada that are considered crop wild relatives (Brouillet et al. 2010; Kantar et al. 2015). However, many berries and fruits have wild relatives in Canada that belong to the primary genepool for breeding and were domesticated here. Canada has many crop wild relatives that belong botanically to the same genera as cultivated plant species and thus represent crop wild relatives or genetic resources of the secondary and tertiary genepools for important crops according to the genepool concept of Harlan and De Wet (1971). Catling and Cayouette (1994) emphasized that in particular in small fruits, berries, and nuts, unique endemic genetic resources occur in the Gaspé Peninsula of Québec.

Catling and Porebski (1998) added to the understanding of these native Canadian plant genetic resources by identifying 56 taxa of rare wild plants that are the highest priority for protection on the basis of both rarity and economic value and pointed out that $60 \%$ of these taxa occur in the Carolinian zone, which includes the Lake Erie lowland region in Ontario, which is densely populated and in which a decline in crop wild relative populations has been reported by these authors. The map provided in Fig. 2.4 singles this area out as being potentially rich in crop wild relatives.

One should note that the plant taxa found in endangered grasslands of Canada have largely been unexplored for their potential economic impact. Figure 2.4 demonstrates, based on 39 crop species, that the areas of the highest potential concentration of crop wild relative species are also the most densely settled areas of Canada, and hence the areas most threatened by genetic erosion. At the same time, these areas have the highest number of alien species and alien invasive species (compare Fig. 2.3) competing with native species. Figure 2.4 is an approximation, as only 39 


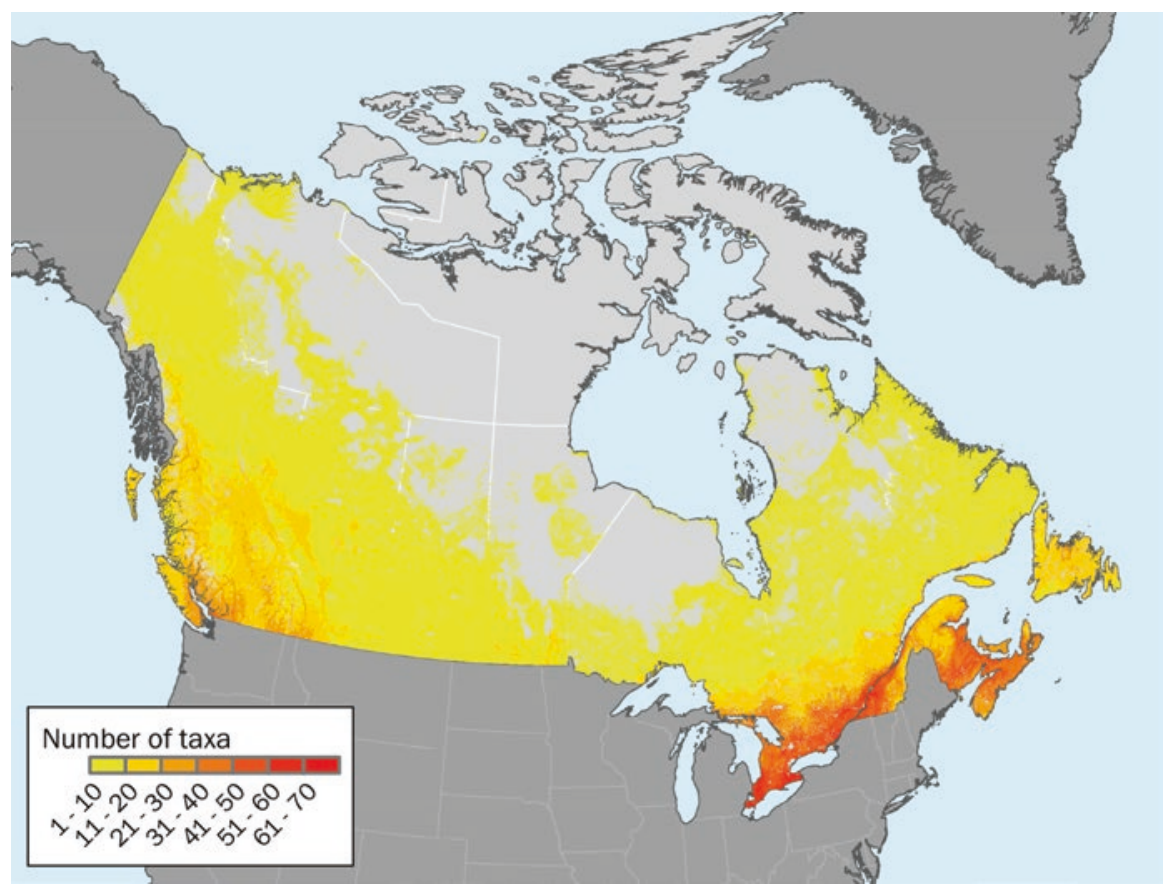

Fig. 2.4 Estimated potential richness of taxa in Canada that are crop wild relatives based on 107 species and 16 genera using data of climatic and edaphic similarities of the assessed area with herbarium and genebank reference localities. Richness of potential distributions of crop wild relative taxa increases from yellow to red. The method for generating the map and a list of reference data providers is given in Appendix 1. Based on online database: Crop Wild Relatives and Climate Change (2013)

crop species were considered and only the data of collection holdings in genebanks and herbaria collections that have been digitized was used to generate this map.

Despite being less rich in species and intraspecific diversity, the arctic regions of Canada also deserve attention as reservoirs of plants with special adaptation, in particular grasses and sedges (Small and Cayouette 2016). The arctic and subarctic ecosystems are very fragile and massively impacted by climate change (Richards 2006).

Many native Canadian plant species, despite not being wild relatives of important cultivated plant species, have great potential for food and agriculture. Indigenous people have used many of these prior to European immigration, and cultivation of some of them is more recent. Marles et al. (2000) compiled information on more than 200 species in Canada's northwest boreal forest used by indigenous people for nutrition or as sources of functional foods, nutraceuticals, or medicines. Arnason et al. (1981) listed 175 species for food, 52 for beverages, and 400 for medicinal use by indigenous people in Eastern Canada. The majority of these species are native to Canada. The fruit crops have become of particular economic relevance, but their potential has not yet been fully developed (St-Pierre 1992; Catling and Cayouette 
1994). Among these, blueberry (Vaccinium myrtilloides L.) and cranberry (Vaccinium macrocarpon Aiton), as well as related Vaccinium species, have been the basis for increased production and are an important contributor to farm income in Canada. In Western Canada, the introduction of blue honeysuckle (Lonicera caerulea L.) as a new crop is an example of successful exploration of native and foreign genetic resources, and collections were made in Canada (Bors 2009). Juneberry (Amelanchier alnifolia Nutt.), also known as saskatoon berry, is another fruit in which Canada is a world resource for unique native genetic diversity (Catling and Cayouette 1994). Small (2014) has recently provided a compendium of 100 species of indigenous food plants from North America covering the area of the United States, Mexico, and Canada with emphasis on species of greatest economic potential. Among the many berries and medicinal plants that were used by the indigenous people of Canada, there are rare species that have not been explored for cultivation (Turner 1981). Cultivation may be a solution to avoid them being over-collected from the wild due to increased interest in natural medicines and natural foods.

Despite the mentioned efforts, agricultural research and public breeding in Canada has during the last two decades narrowed its focus to major crops. Research on native species has languished resulting in the potential of many native species being unrealized. Even in the important native berry and fruit species, the public sector and universities have reduced their activities and breeding of these crops. Three factors are largely responsible for neglecting the potential of native Canadian plant diversity for cultivation. Firstly, European immigration changed land-use patterns drastically by establishing agriculture in the areas suitable for that activity. This resulted in agroecosystems replacing natural ecosystems with major changes in species composition and also causing loss of native plant diversity that had potential for cultivation. Secondly, the major influx of immigrants, starting in the middle of the nineteenth century, made it necessary for the Canadian government to support these immigrants immediately and effectively by introducing familiar crops from the Old World that had proven yield potential but needed to be adapted to the local conditions of different regions of Canada. This was essential for national food security in Canada at that time and has been the priority ever since, as Canada became a main exporter of agricultural products during the twentieth century. Cereal research dominated until the middle of the twentieth century, while research in rapeseed and pulse crops is much more recent. Thirdly, much indigenous knowledge about the usages and potential of native Canadian plants has been lost due to the Eurocentric scientific approach that has been dominating the last centuries, and only recently has science started to recognize the relevance of indigenous knowledge.

Canadian Confederation in 1867 and the Experimental Farm Station Act from 1886 were the basis for forming the Research Branch of the Department of Agriculture for Canada in 1886 (Anstey 1986), which today is the Science and Technology Branch of the Department of Agriculture and Agri-Food Canada (AAFC). During the late nineteenth and early twentieth centuries, Canada actively invited immigrants to settle the arable area that now forms part of the three Prairie Provinces, Manitoba, Saskatchewan, and Alberta, which became the most important areas for agricultural production in Canada (Fig. 2.2). The Central Experimental 
Farm in Ottawa, Ontario, distributed seed samples of improved crops to farmers. In 1889, 3700 packages of seeds were distributed mostly to farmers (Anstey 1986). These seed packages were larger than the 100 seeds per sample a modern genebank ships to its clients, which are today mostly plant breeders and other researchers. Parenthetically, the Canadian genebank Plant Gene Resources of Canada (PGRC) today also ships about 4000 seed samples annually. Dominated by European immigration and mindset, research on utilization in agriculture rarely focused on native plant species for potential cultivation. As a consequence, large ex situ research collections that entered the Canadian national genebank, PGRC, were established for the crops and crop wild relatives of the cereals oat, barley, and wheat, all of nonCanadian origin. Even within these cereals, the native Canadian taxa were neglected. Similarly, native Canadian grasses, legumes, and other native Canadian forage species have not received much attention. Indigenous people have utilized the medicinal properties of native Canadian species for centuries, and some records exist of their usage by early immigrants. However, over time synthetic drugs have gained much more attention from research, and only toward the end of the twentieth century, the efficacy of several native species as herbal medicines and food sources has become more widely recognized (Arnason et al. 1981; Turner 1981 and Marles et al. 2000). European explorers of Canada that arrived following John Cabot's landing on the Canadian Atlantic coast in 1497 definitely had the exploitation of resources in mind, but the agricultural use and the wild plant use by the indigenous people was not well-respected and only poorly documented (Asselin et al. 2014, 2015, 2017). We are still in the initial stages of realizing the potential of native Canadian plant genetic resources for food and agriculture, medicinal usage, or other purposes (Small 1999). We have lost indigenous Canadian knowledge and know-how, but new knowledge and know-how has also been brought and generated by the European settlers when adapting to the Canadian environment. In addition, indigenous people have also started to use and learn about the new plants that came to Canada.

\subsection{Plant Genetic Resources Conservation and Use Policies of Canada in the International Context}

Canada was among the first countries to sign the Convention on Biological Diversity (CBD) agreed upon in Rio de Janeiro in 1992 and ratified it the same year (Harvey and Fraleigh 1995). The secretariat of the CBD is located in Montreal, Québec, underlining the high status of this agreement in Canada. Following the CBD ratification, Canada formulated a Canadian Biodiversity Strategy (Minister of Supply and Services Canada 1995). The Canadian Department of Agriculture (Agriculture and Agri-Food Canada, AAFC) published inventories of industry and departmental initiatives related to the Canadian Biodiversity Strategy (Agriculture and Agri-Food Canada 1997a, 1997b). Provinces such as Québec also responded by developing an implementation strategy and an action plan (Gouvernement du Québec 1996a, 1996b). In 2004, the Canadian Council of Ministers of the Environment created the 
"federal, provincial, and territorial working group on biodiversity", which formulated the "2020 Biodiversity Goals and Targets for Canada" and a Canadian Biodiversity Strategy (Federal, provincial and territorial working group on biodiversity 2016). Canada presented four goals covering 19 targets that relate to the 20 Aichi Biodiversity Targets of the CBD (CBD 2016a). Canada has developed a Federal Sustainable Development Strategy, and environmental indicators have been established (Environment and Climate Change Canada 2016a). Besides the protection of species at risk, these targets also address biodiversity at the landscape level, including agricultural working landscapes. The Canadian federal, provincial, and territorial working group on biodiversity initiated the further development of domestic access and benefit-sharing policy in Canada that also addresses aspects of traditional knowledge.

Finalization of this Canadian policy is very close. The Nagoya Protocol on Access to Genetic Resources and the Fair and Equitable Sharing of Benefits Arising from their Utilization (ABS) of the Convention on Biological Diversity, adopted at the tenth meeting of the Conference of the Parties in Nagoya, Japan on 29 October 2010, has not yet been signed by Canada, and, therefore, it is not legally binding on Canada. The Nagoya Protocol entered into force on 12 October 2014. Presently, Canada is considering becoming a party to the Nagoya Protocol, but a final decision is still pending. The national lead for the CBD and Nagoya Protocol is the Department of Environment and Climate Change Canada.

The International Treaty on Plant Genetic Resources for Food and Agriculture (ITPGRFA), adopted in 2001 and signed and ratified by Canada on 10 June 2002, focuses on plant genetic resources for food and agriculture, including crop wild relatives. Canada has been actively involved in negotiating this Treaty, and the Canadian Department of Agriculture is the national lead in negotiations and implementation of the ITPGRFA (Fraleigh and Harvey 2011). The ITPGRFA entered into force on 29 June 2004. Canada is very aware of the international interdependencies for global and national food security, and of the fact that the international exchange of genetic resources for cultivated plants is critical for sustainability both nationally and globally. Canada is particularly dependent on access to genetic resources internationally because most important agricultural crops have their origin outside of the country. Canada also supports the fair and equitable sharing of benefits arising from the use of plant genetic resources which motivates the strong engagement of Canada in the ITPGRFA. Canada recognizes the ITPGRFA as the basis for all plant genetic resources for food and agriculture and made all its genetic resources holdings at the national genebank, Plant Gene Resources of Canada (PGRC), available nationally and internationally under the provisions of the Standard Material Transfer Agreement of the ITPGRFA. This also includes the native Canadian germplasm held by PGRC.

Within Canada, national legislation impacts the diversity of cultivated plants, weeds, and crop wild relatives. The regulatory agency for implementing these laws is the Canadian Food Inspection Agency (CFIA). The Plant Protection Act of 1990 prohibits the import or spread of pests or any other agents that may cause harm to agricultural or forestry plants in Canada (Minister of Justice 2016a). The Seeds Act of 1985 refers to the registration of varieties of cultivated plants but also seed trade 
and movement of seeds (Minister of Justice 2016b). As such, the Seeds Act includes a regulation with a list of species considered as weeds based on the potential harm they may cause to Canadian agriculture and the environment. The list includes crop wild relatives such as Aegilops cylindrica Host, Elymus repens (L.) Gould, Datura stramonium L., Raphanus raphanistrum L., Avena fatua L., A. sterilis L., Pastinaca sativa L., and Daucus carota L. In addition, many Canadian provinces have a Weed Control Act with lists of plants in categories according to the degree of harm they may cause in the region. In 2004, Environment Canada (the name of the department changed to Environment and Climate Change Canada in 2015) developed an invasive alien species strategy for Canada in which it clearly expressed the lack of taxonomic benchmarks and expertise that is critical to act on these issues (Environment and Climate Change Canada 2016b). Strong concerns regarding the taxonomic expertise in Canada were articulated by Small et al. (1995): "Little wonder there is increasing doubt that Canada can adequately protect its own biodiversity." More recently, the Council of Canadian Academics (2010) also expressed concerns in this regard.

The Species at Risk Act from 2002 (Minister of Justice 2016c) is administered by the Canadian Endangered Species Conservation Council, consisting of the Minister of Environment and Climate Change, the Minister of Fisheries and Oceans, the Minister responsible for the Parks Canada Agency, and provincial or territorial ministers responsible for the conservation and management of wildlife species in that province or territory. The Species at Risk Act (Minister of Justice 2016c) was created to be compliant with the CBD, and its main purpose is to protect wildlife species from being extirpated or becoming extinct and to help reestablish lost species. It includes lists of organisms of all kingdoms by species categorized as being extinct, extirpated, endangered, threatened, or of special concern. These lists are updated regularly by the Committee on the Status of Endangered Wildlife in Canada (COSEWIC) and can be inspected on the Internet (COSEWIC 2017).

Canadian policies relevant for the use of plant genetic resources for food and agriculture include the Canadian Plant Breeders' Rights Act from 1990, which was updated in 2015. It now includes provisions that bring it into line with the 1991 amendment of the Convention of the International Union for the Protection of New Varieties of Plants (Minister of Justice 2016d; UPOV 2016).

Canada has been involved in the CBD from the very beginning. Individuals that act as Canadian National Focal Points for several topics including one for the Nagoya Protocol have been nominated (CBD 2016b). Additionally, Canada is actively engaged in the work of the Food and Agriculture Organization (FAO) of the United Nations Commission on Genetic Resources as well as in the ITPGRFA and has National Focal Points for each of them (FAO 2016a, 2016b). This was of particular relevance as Canada had been the only partner country from the North American region that had ratified the ITPGRFA until September 2016, when the United States joined the ITPGRFA. Several Canadian provinces have developed biodiversity strategies in line with targets from the CBD. On the provincial level, biodiversity related to food and agriculture receives less attention than biodiversity of wild and native species. 


\subsection{Ex Situ Conservation}

\subsubsection{National Germplasm Collections}

Three research centers of Agriculture and Agri-Food Canada share the responsibility for active national genebank work in plant genetic resources for food and agriculture: (1) Plant Gene Resources of Canada (PGRC) at the Saskatoon Research and Development Centre, Saskatoon, Saskatchewan, preserves all seed germplasm, has the central seed storage vaults, and maintains the national genebank information system (GRIN-CA/GRIN-Global-CA) that allows national and international clients and the public to inspect and access Canadian genebank holdings (PGRC 2016); (2) the Canadian Clonal Genebank (CCGB) at the Harrow Research and Development Centre, Harrow, Ontario, preserves fruit germplasm; and (3) the Canadian Potato Genetic Resources (CPGR) at the Fredericton Research and Development Centre, Fredericton, New Brunswick, preserves potato germplasm. The mandate of PGRC is to acquire, preserve, evaluate, and make available the genetic diversity of cultivated plants and their wild relatives with emphasis on germplasm of economic importance or potential for Canada. The germplasm holdings of PGRC and the associated locations currently include 110,442 accessions covering 47 botanical families, 258 genera, and 980 botanical species (Fig. 2.5). Passport, characterization, and evaluation data are accessible via the Internet (PGRC 2016). The cereals, barley, oat, and wheat account for more than $80 \%$ of all germplasm holdings. Extensive collections of crop wild relatives exist at PGRC for barley, oat, and wheat, which are important to Canada (Table 2.1). In these groups the proportion represented by crop wild relatives amounts to $30 \%$ of the PGRC collection due to intensive collection with Canadian participation of such material in the second half of the twentieth century. Although these wild and weedy crop wild relatives are mostly not

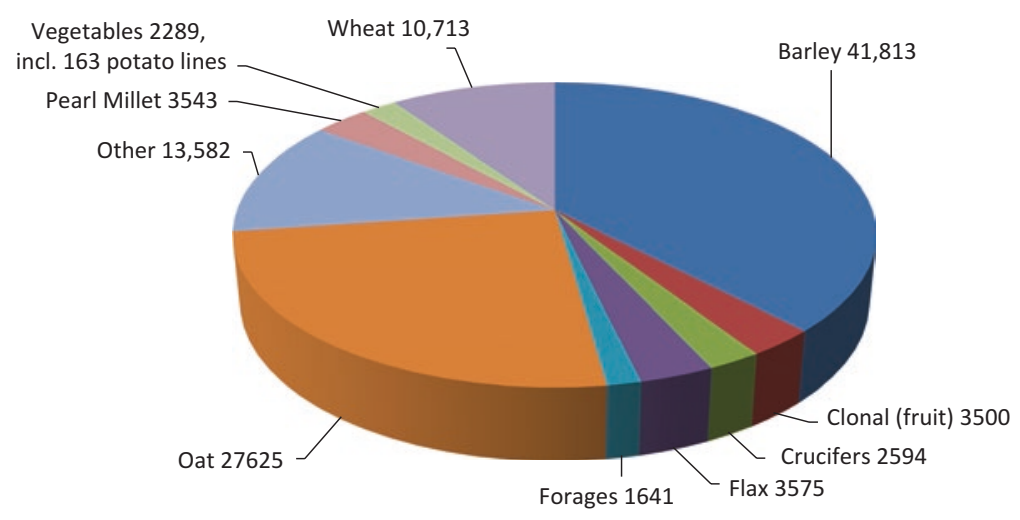

Total: 110,442 accessions of 980 species

Fig. 2.5 Germplasm holdings at Plant Gene Resources of Canada. (Number of accessions) 
Table 2.1 Number of cultivated and wild taxa and accessions of cereals at Plant Gene Resources of Canada (PGRC)

\begin{tabular}{l|l|l|l|l|l|l}
\hline Genus & Total & \multicolumn{2}{|l|}{ Cultivated } & Wild & Proportion \\
\hline & Accessions & Taxa & Accessions & Taxa & Accessions & Wild accessions (\%) \\
\hline Aegilops L. & 632 & - & - & 22 & 632 & 100 \\
\hline Avena L. & 27,790 & 6 & 12,502 & 25 & 1,5288 & 55 \\
\hline Hordeum L. & 41,813 & 2 & 38,858 & 38 & 5955 & 14 \\
\hline Triticum L. & 11,345 & 21 & 8357 & 4 & 2988 & 26 \\
\hline Total & 81,580 & 51 & 59,717 & 67 & 24,863 & 30 \\
\hline
\end{tabular}

of Canadian origin, they are important from a national and global perspective, as many were collected in the 1970s to 1990s in regions of the world that are today not easily accessible for such collecting (Baum et al. 1972). Utilization of crop wild relatives in disease resistance breeding has been particularly strong in Avena L. (Diederichsen 2016) but also in the genera Triticum L., Aegilops L., and Secale L. By preserving and providing access to these genetic resources, Canada makes significant contributions to the global efforts to conserve and utilize crop wild relatives.

GRC's main germplasm holdings include many accessions for which the GRIN-CA database lists the country of origin as Canada and the accession status as wild. These native Canadian plants include many species that are used as forages (e.g., purple prairie clover, Dalea purpurea Vent., Medicago L. spp., other legume species, several grasses), some that are used as medicinal or ornamental plants (e.g., genera Monarda L., Mentha L., and Rhodiola L.), many that are berries (e.g., raspberry, elderberry, blackberry, cranberry, gooseberry, blueberry, and currant), some that are crops (e.g., Helianthus tuberosus), many that are crop wild relatives (e.g., genera Helianthus and Hordeum), and many grass species that are interesting genetic resources from the perspective of food and agriculture. Weed species also deserve greater attention in this context. Several weeds have potential as genetic resources for utilization, including both native Canadian and naturalized species, and several are threatened by extinction. Some weeds have features similar to crops (convergent evolution with cultivated plants) which ensured their survival in farmers' fields prior to use of herbicides. An example for Canada is cow cockle (Saponaria vaccaria L.), which has recently received attention for cultivation in Western Canada due to its saponin content (Mazza et al. 1992; Willenborg and Johnson 2013) and earlier in the United States as a source of starch (Goering et al. 1966). The weed plants could easily become secondary cultivated plants, similar as oats and rye evolved from weeds in historic times (Vavilov 1926; Hammer et al. 1997). Also weeds with features showing divergent evolutionary features from cultivated plants can have the potential to become secondary cultivated plants, such as purslane (Portulaca oleracea L.) which is a popular salad plant among East Asian immigrant populations in Canada. They also represent a genetic resource for food and agriculture.

PGRC currently does not have a strong program focusing on ex situ conservation of native Canadian germplasm. The need to strengthen such activities was expressed 
Table 2.2 Special collections of native Canadian germplasm at Plant Gene Resources of Canada (PGRC)

\begin{tabular}{|c|c|c|c|c|}
\hline $\begin{array}{l}\text { Name of } \\
\text { collection at } \\
\text { PGRC }\end{array}$ & Collector & $\begin{array}{l}\text { Year of } \\
\text { collecting }\end{array}$ & Type of material & $\begin{array}{l}\text { Number of } \\
\text { accessions }\end{array}$ \\
\hline $\begin{array}{l}\text { Main Collection } \\
\text { of Native } \\
\text { Canadian Plant } \\
\text { Material }\end{array}$ & $\begin{array}{l}\text { Plant Gene Resources of } \\
\text { Canada and collaborators } \\
\text { (Richard G. St-Pierre, } \\
\text { Kenneth W. Richards) }\end{array}$ & $\begin{array}{l}\text { Started } \\
\text { 1996, } \\
\text { ongoing }\end{array}$ & $\begin{array}{l}\text { Many taxa, mostly } \\
\text { from Western Canada, } \\
\text { focus on forages, } \\
\text { grasses, and species of } \\
\text { economic potential }\end{array}$ & 1964 \\
\hline $\begin{array}{l}\text { ON \& QC Rare } \\
\text { Species } \\
\text { Collection }\end{array}$ & $\begin{array}{l}\text { Montréal Botanical } \\
\text { Garden, Québec (Alain } \\
\text { Meilleur, Frédéric } \\
\text { Coursol, André Sabourin, } \\
\text { Nadia Cavallin) }\end{array}$ & 2006-2007 & $\begin{array}{l}\text { Black box collection, } \\
\text { various species }\end{array}$ & 90 \\
\hline $\begin{array}{l}\text { Manitoba } \\
\text { Orchid Society } \\
\text { Collection }\end{array}$ & $\begin{array}{l}\text { Manitoba Orchid Society } \\
\text { (Richard G. St-Pierre) }\end{array}$ & 2006-2010 & Orchid seeds & 58 \\
\hline $\begin{array}{l}\text { Canadian Arctic } \\
\text { Collection }\end{array}$ & $\begin{array}{l}\text { Alaska Plant Materials } \\
\text { Center, Palmer, Alaska, } \\
\text { United States, (Stoney } \\
\text { Wright) }\end{array}$ & 2004,2005 & $\begin{array}{l}\text { Emphasis on grasses } \\
\text { with adaptation to } \\
\text { coastal, subarctic } \\
\text { conditions of Eastern } \\
\text { Canada }\end{array}$ & 870 \\
\hline $\begin{array}{l}\text { Northwest } \\
\text { Territories } \\
\text { Collection }\end{array}$ & $\begin{array}{l}\text { Aurora Institute, } \\
\text { Northwest Territories, } \\
\text { Canada (Pippa } \\
\text { Seccombe-Hett, Annika } \\
\text { Trimble, Ashley Mercer) }\end{array}$ & 2005-2007 & $\begin{array}{l}\text { Wide range of native } \\
\text { species native to the } \\
\text { Northwest Territories }\end{array}$ & 323 \\
\hline $\begin{array}{l}\text { Symbios } \\
\text { Research and } \\
\text { Restoration } \\
\text { Collection }\end{array}$ & $\begin{array}{l}\text { Symbios Research and } \\
\text { Restoration, Smithers, } \\
\text { British Columbia (Philip } \\
\text { J. Burton) }\end{array}$ & 1996-1999 & $\begin{array}{l}\text { British Columbian } \\
\text { species which have } \\
\text { potential for habitat } \\
\text { restoration }\end{array}$ & 357 \\
\hline $\begin{array}{l}\text { Native Bromus } \\
\text { Collection }\end{array}$ & $\begin{array}{l}\text { Agriculture and } \\
\text { Agri-Food Canada } \\
\text { (Bruce Coulman, Jacques } \\
\text { Cayouette) }\end{array}$ & 1993-1998 & $\begin{array}{l}\text { Mostly Bromus species } \\
\text { from Western Canada }\end{array}$ & 42 \\
\hline
\end{tabular}

previously and is especially pressing since the vulnerability of native species to climate change is particularly high in Canada (Richards 2006). Systematic efforts to collect native Canadian plant diversity for ex situ conservation have only been conducted on a limited scale by collaborators of PGRC within Canada or from abroad. For example, in 2004 and 2005, Stoney Wright, a scientist from Alaska, United States, collected grasses with adaptation to arctic/subarctic conditions of Northern Québec, Nunavut, and the Northwest Territories. The Aurora Research Institute in the Northwest Territories collected seed of native species for use in reclamation projects (Aurora Institute 2016). Seed samples from such collection activities have been deposited in PGRC (Table 2.2), and selected grass and forage species from these collections have been regenerated and integrated into the active PGRC genebank collection. PGRC also preserves seeds of native Canadian material as 
security-backup samples (black box collections) for Canadian botanical gardens. These seeds are not tested for viability or researched in any other way by PGRC. Requests for material from all these special collections are treated differently than requests for germplasm from the main PGRC collections, and these special collections are not listed on the PGRC Internet website.

Interest by PGRC clients in native Canadian germplasm has been the reason for targeted collecting missions. The beer brewing industry in the Czech Republic was looking for native material of hops (Humulus lupulus L.) that was collected in Saskatchewan and Manitoba in 2003 for hop breeding and proved to be chemically distinct from European and other North American plants; the Canadian material was also found to have powdery mildew resistance (Patzak et al. 2010). The recent interest in false flax (Camelina sativa (L.) Crantz) has also resulted in collecting of crop wild relatives of this genus in Canada (Séguin-Swartz et al. 2013; Martin et al. 2015). However, limited capacities in the national Canadian genebank do not allow for ex situ conservation of all diversity of all native species that are plant genetic resources for food and agriculture, and priorities need to be established. In evolutionary terms, it is definitely preferable to maintain crop wild relative germplasm in situ in their native habitats, although access is facilitated by ex situ conservation. The ongoing discussion on the advantages, the disadvantages, and the feasibility of these two conservation principals is complex, has political implications, and started on the international level in the 1960s (Pistorius 1997; FAO 2016c).

Ornamental use of native species is also important. In rose breeding, two major rose cultivar series have been bred in Canada: The so-called series of Explorer roses bred by F.D. Svejda (1920-2016) are the basis for the series of Parkland roses and the Artist roses, which are based on introgression of adaptation traits from wild native species (Richer et al. 2007). Many other native trees, shrubs, and perennial and annual species have been identified that have potential value as ornamentals (Davidson 1995). Local industries promoting native plants for ornamental use can be found across Canada, and numerous websites exist for native plant societies in several Canadian provinces (North American Native Plant Society 2016). Currently, the main use for native species is in reclamation projects undertaken by the mining industry or other projects with massive landscape intervention.

\subsubsection{Other Germplasm Collections of Native Canadian Crop Wild Relatives Within Canada}

Working collections of fruit germplasm native to Canada exist at universities and at Agriculture and Agri-Food Canada research centers for research purposes. However, many fruit breeding programs have ceased. Some of these collections, such as strawberry, saskatoon berry (Amelanchier spp.), and rosehips (Rosa spp.), have been transferred to the Canadian national genebank system and are mostly preserved at the Canadian Clonal Genebank at Harrow, Ontario (PGRC 2016). The Canadian Food Inspection Agency maintains reference collections of fruit 
germplasm with emphasis on cultivars at Saanich, British Columbia; here, phytosanitary concerns are the primary purpose of the collection since virus diseases are regulated when such germplasm is transferred. However, the content of these collections is only accessible after inquiring directly to the respective institutions. A Canadian university collection containing native germplasm is accessible to the public from the Prairie Fruit Genebank established in the early 2000s at the University of Saskatchewan. This collection contains diverse material of native Canadian species such as blue honeysuckle (Lonicera caerulea L.), currant (Ribes spp.), raspberry (Rubus idaeus L.), and highbush cranberry (Viburnum trilobum Marsh.) (University of Saskatchewan 2016). The successful introduction of blue honeysuckle as a commercial crop in Western Canada is a recent example of utilization of native Canadian genetic resources (Bors 2009). Similarly, Fofana and Sanderson (2015) developed a new semidomesticated rosehip (Rosa hybrid) using native Canadian germplasm, and such germplasm was deposited at the Canadian Clonal Genebank of AAFC at Harrow, Ontario. In grapevine breeding, the Canadian native species Vitis riparia Mixch. has had great impact for introgressing adaptive traits into imported and less adapted grapevine (Reynolds et al. 2015).

A similar situation as for fruit germplasm exists for native Canadian grasses, forage legumes, and rangeland species. Native Canadian prairie vegetation has experienced a great decrease in area, from $61.5 \mathrm{M}$ ha prior to European settlement to 11.4 M ha in recent years based on Statistics Canada Census 2006 and earlier published data (Bailey et al. 2010). This is partly due to policies that encouraged settlement and land utilization for annual crops (Bailey et al. 2010). Jefferson et al. (2005) identified some of the potential benefits of native plant species that have not received adequate attention. Cayouette et al. (1997) and Neufeld (2010) identified increasing interest in native plant species for reclamation, horticultural, and forage purposes. Some breeding of native species, which are registered as so-called Ecovars ${ }^{\mathrm{TM}}$, has existed in Western Canada since the 1990s (May et al. 1997). Initially, several AAFC research facilities and the University of Manitoba were involved with Ducks Unlimited Canada Ecovars ${ }^{\mathrm{TM}}$ in developing such material and a list of 24 suggested species of native grasses, legumes, and shrubs. As of 2016, AAFC Swift Current Research and Development Centre is the only facility still researching the collected material. Species that were registered from Swift Current include awned wheatgrass (Elymus trachycaulus (Link) Gould ex Shinners subsp. subsecundus (Link) Á. Löve \& D. Löve), little bluestem (Schizachyrium scoparium [Michx.] Nash var. scoparium), northern wheatgrass (E. lanceolatus (Scribn. \& J. G. Sm.) Gould subsp. lanceolatus var. lanceolatus), western wheatgrass (Pascopyrum smithii [Rydb.] Barkworth \& D. R. Dewey), plains rough fescue (Festuca hallii [Vasey] Piper), and Canadian milkvetch (Astragalus canadensis L. var. canadensis). Initially, this effort focused on revegetation needs, but continued research has focused on agricultural needs. This ongoing research has found characteristics within the native plant species that provide benefits beyond forage use. Purple prairie clover (Dalea purpurea), for example, was found to have a condensed tannin profile that decreases the shedding of Escherichia coli bacteria in cattle (Jin et al. 2015). Winterfat (Krascheninnikovia lanata [Pursh] Meeuse \& Smit), a winter forage shrub, is noted 
as improving digestibility of low-quality plant material when ingested together (Schellenberg 2005). Utilization of the native legume Thermopsis rhombifolia (Nutt. ex Pursh) Richardson is also being investigated for medical purposes such as anticancer effects in humans (Kerneis et al. 2015). The relevance of native perennial bromegrass as forage has been emphasized (Cayouette et al. 1997). As stated previously, the potential of native Canadian plant species is largely unexplored, but the preceding examples provide a small insight into the potential benefits of further exploration, hopefully before the resource no longer exists.

Botanical gardens have an important role in conservation biology. Canada has about 100 botanical gardens, arboreta, and related facilities, and many of them are active in the Botanic Gardens Conservation International initiative (BGCI 2016). For crop wild relatives and for accessing germplasm, the following institutions are most relevant: Devonian Botanical Garden, Edmonton, Alberta; Montreal Botanical Garden, Montreal, Québec; Royal Botanical Gardens, Burlington-Hamilton, Ontario; and UBC Botanical Garden, Vancouver, British Columbia. The Montreal Botanical Garden has projects that relate in particular to ethnobotany involving indigenous people from Canada. The Canadian Botanical Conservation Network (CBCN) is a project of the Royal Botanical Gardens, which was established in 1995 and has the objective to coordinate conservation activities among different institutions. It is linked to the North American botanic garden strategy for plant conservation (BGCI 2016) and provides information into the COSEWIC species at risk assessments for Canada. Botanical gardens in Canada do not systematically research the aspects of utilization of native plants for food and agriculture. In addition, intraspecific diversity, which is the genetic diversity of great relevance for utilization, is rarely featured by botanical gardens because mostly the species as such is the category of concern and not the diversity within a species. However, this aspect of

genetic diversity has recently gained some momentum both in botanical gardens within Canada and internationally.

\subsection{In Situ Conservation}

In situ conservation is of great relevance for native Canadian species. In 2015, about $10.6 \%$ of Canada's terrestrial area was protected and under governance of the federal or provincial governments (Fig. 2.6, Environment and Climate Change Canada 2016b). However, the locations of these protected areas are either far from human settlement or of high recreational value, both of which impact biodiversity. The areas of greatest relevance for agriculture, such as the arable prairie areas, the mixed wood plains of Southern Ontario, and the regions along the St. Lawrence River, cover less than $2 \%$ of the area protected (Anonymous 2014). Therefore, crop wild relatives located in these regions benefit little from this type of protection. A comparison of the species rich (dark red) areas in Fig. 2.4 in Southern Ontario with the lack of protected areas in the same regions in Fig. 2.6 illustrates this discrepancy. Some areas are floristically of great relevance, such as the alvars in Western Québec 


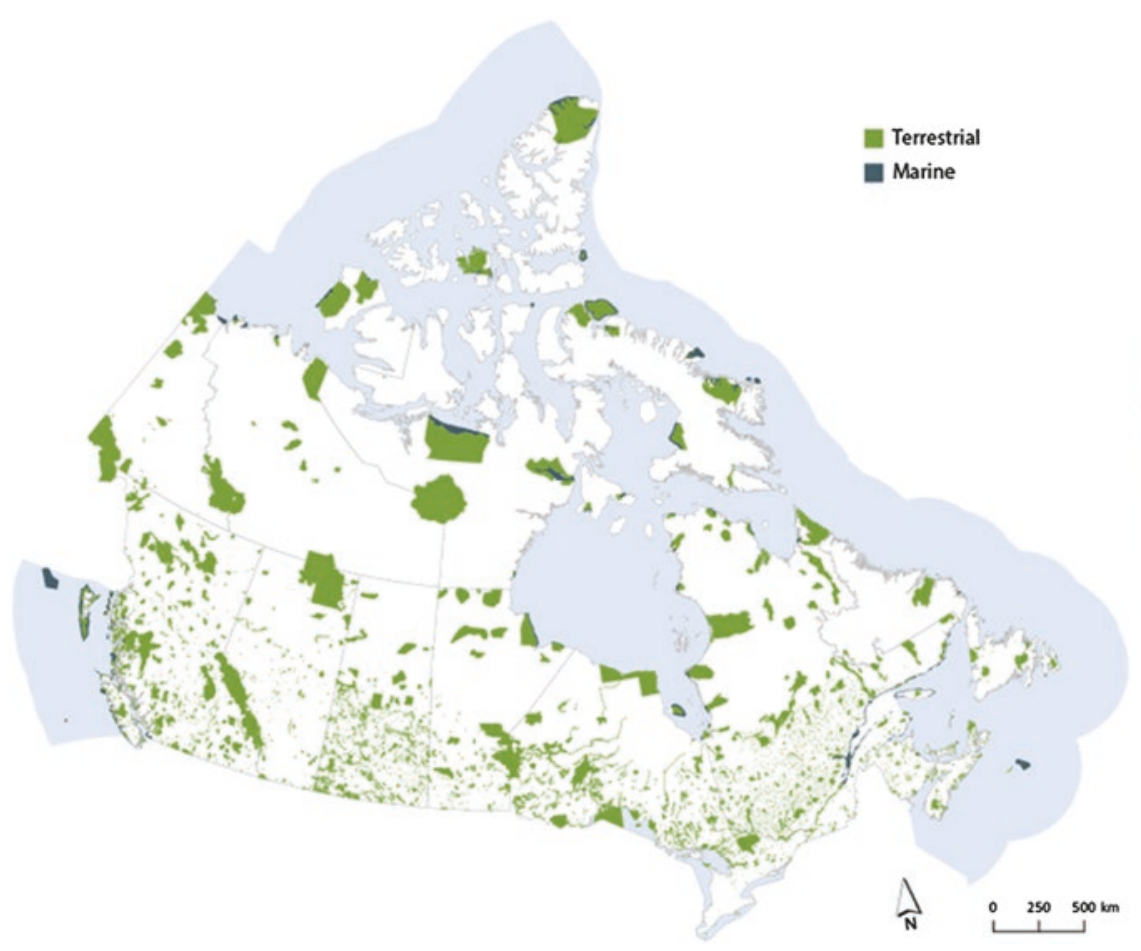

Fig. 2.6 Distribution and size of terrestrial (land and freshwater) protected areas in Canada and marine protected areas in 2015. (Environment and Climate Change Canada 2016c)

and in Ontario, which are open habitats on thin soil over calcareous beds. They harbor a lot of rare native species that are genetic resources.

Climate change impacts all biodiversity and agriculture massively. Urbanization in the densely settled areas is another challenge. Agroecosystems for in situ conservation of crop wild relatives are important to consider and a fairly new concept. In addition to the protected areas, there are 18 UNESCO biosphere reserves in Canada. These are not static in their conservation work but integrate sustainable human activities and pay particular respect to indigenous people (Canadian Biospheres Reserves Association 2017). Populations of crop wild relatives are affected by all measures taken by agriculture. Great selection pressure comes from pesticide use. Many weeds that are crop wild relatives became rare species today. Weeds are rarely seen as being worthy of conservation because of two tendencies: botanical science neglects them and agricultural science combats them. Carr (1993) pointed out the potential of stinkweed (pennycress, fanweed, Thlaspi arvense L.), a very common weed of Western Canada. The biofuel industry has started to work with this species (Dorn et al. 2015). PGRC has 23 accessions of this species in its collection and contributed to research by providing such germplasm.

The possibility of gene flow integrating herbicide tolerance into weeds and crop wild relatives is a reality in Canada, and this phenomenon is accelerating. An example was provided by Séguin-Swartz et al. (2013) for species within the genus 
Camelina that are naturalized in Canada. Martin et al. (2015) showed that the more distant Capsella bursa-pastoris (L.) Medik., which is also a neophyte in Canada, produces offspring when pollinated with the cultivated species Camelina sativa $(\mathrm{L}$. Crantz. Due to common agricultural practice, the selection pressure for developing herbicide tolerance in Canada is enormous and affects the diversity of weeds and crop wild relatives. Such resistance was found in many weeds in Western Canada including crop wild relative genera of grasses (Bromus L., Hordeum L., Setaria P. Beauv., Elymus L., Avena) and dicotyledonous plants (Lepidium L., Amaranthus L., Sinapis L.) (Beckie et al. 2013). Some of these weed populations may be used as sources for such traits in breeding of the related cultivated species. The most prominent crop wild relative in Canada is Avena fatua. It is not a native species but is decidedly naturalized, widely spread, and well preserved in in situ/on-farm situations. PGRC maintains 644 accessions of this species. It is part of the primary genepool for A. sativa L., and in Canada the two species form a crop-weed complex influencing each other by introgression (Van Raamsdonk and Van der Maesen 1996). The evolutionary response to modern agriculture has resulted in herbicide tolerances in A. fatua, but the wild oat has also been used as a crop on its own (Beckie et al. 2012).

Botanical inventories of species differentiating according to rareness of species in Canada exist. An excellent source for species occurrences in Canada was provided by Brouillet et al. (2010). Citizen scientists and naturalists contribute to knowledge about the Canadian flora. An example of a useful guide to wildflowers for the province of Saskatchewan is provided by Lee (2017). A recent review emphasized the lack of representations of crop wild relatives in genebank collections on the global scale and pointed out the gaps in Canada (Castañeda-Álvarez et al. 2016). Their study did not assess the conservation status of the species (whether they are threatened), which would be important information to justify the major effort of ex situ conservation. Some habitats such as the native prairie are becoming rare, and their species need attention. Examples of crop wild relatives are the sunflower species (Fig. 2.7), native plants with medicinal uses (Fig. 2.8), and native grasses (Fig. 2.9).

Having the utilitarian aspect of genetic resources in mind, it would be helpful to differentiate among wild non-utilized species, wild utilized species, crop wild relatives, weeds, naturalized species, and cultivated species or taxa. The genepool concept of Harlan and De Wet (1971) could be used which groups wild species according to their capability to intercross with a cultivated taxon into a primary, secondary, and tertiary genepool. Not all species in the same genus as a crop are necessarily relevant as genetic resources. For example, all native Canadian Hordeum species are genetically very distant from the cultivated $H$. vulgare $\mathrm{L}$. and cannot be used in traditional plant breeding; if anything, they belong to the tertiary genepool for barley breeding. Taxonomic studies are needed in many species to clarify these relationships. Another challenge is that many native species, in particular rangeland species, are not known for their potential for food and agriculture.

It is noteworthy that native grassland species and populations have become rarer and disjunct during the course of agricultural settlement in Western Canada. Management of native grassland populations has also changed considerably. 


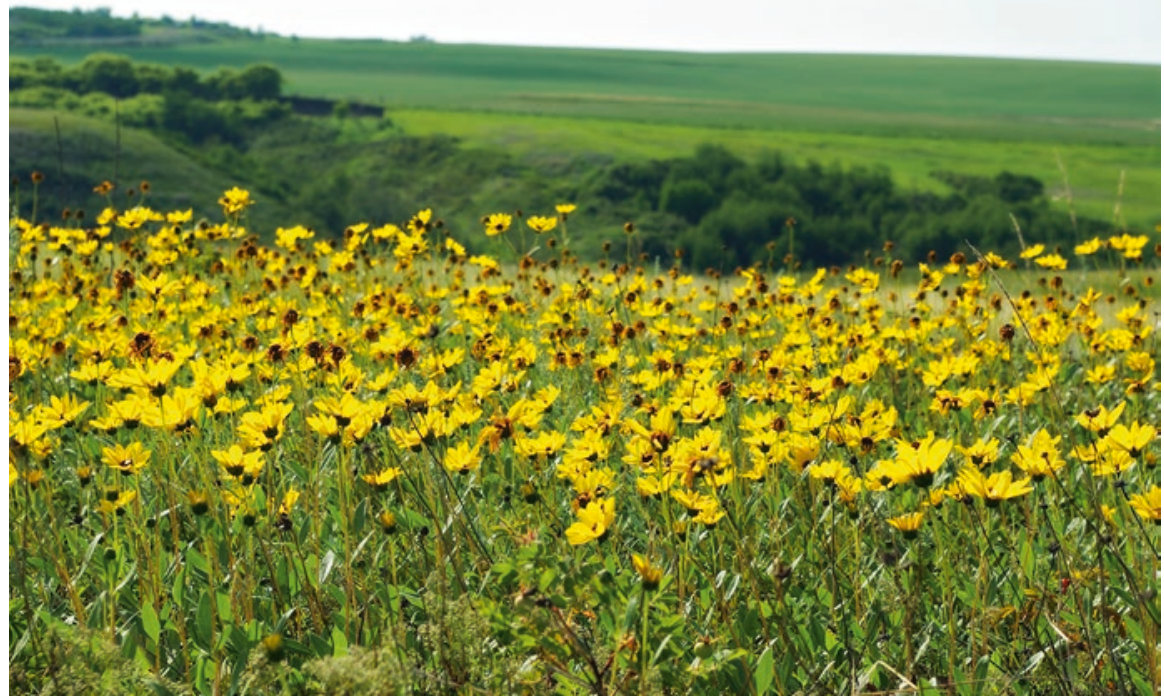

Fig. 2.7 Aspect of Helianthus nuttallii Torrey and A. Gray, a crop wild relative of sunflower, at Eagle Creek, Saskatchewan. (Photo: Maureen Carter)

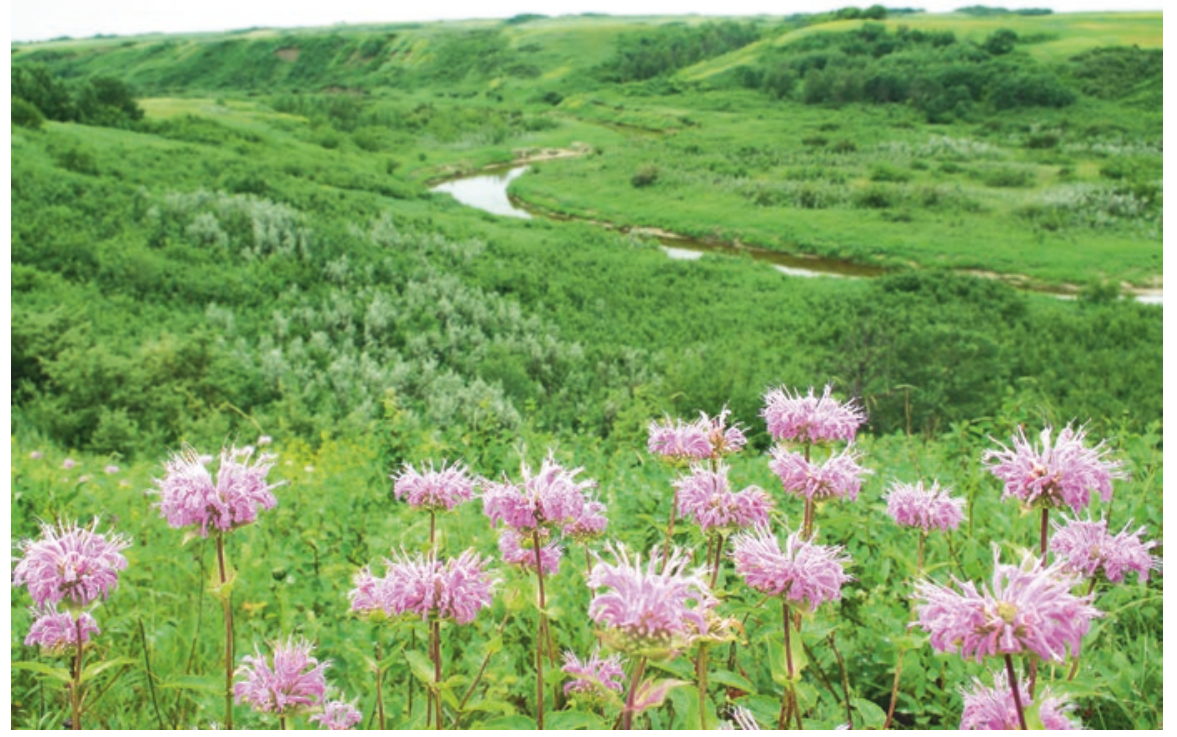

Fig. 2.8 Aspect of wild bergamot (Monarda fistulosa L.), a medicinal and ornamental plant, at Eagle Creek, an Urstromtal (meltwater valley) in Saskatchewan. (Photo: Maureen Carter) 
Fig. 2.9 June grass (Koeleria macrantha [Ledebour] Schultes), a native grass, at Grasslands National Park, Saskatchewan. (Photo: Branimir Gjetvaj)

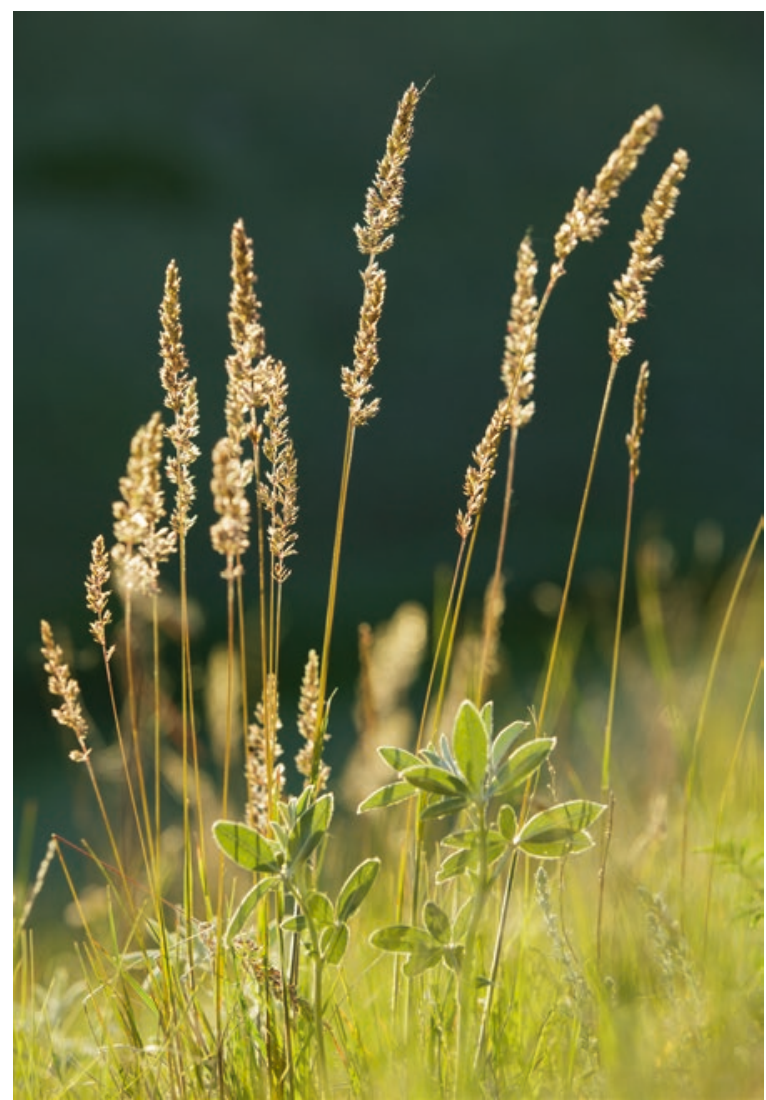

Naturally occurring fires were more frequent prior to settlement, and fire protection measures have changed the habitats. In addition, the Canadian government has reduced its engagement in active management of native rangelands in Western Canada during the last decade. Government-owned land (provincial and/or federal) and pastures administered by the Prairie Farm Rehabilitation Administration (established in 1935 as a result of the prolonged drought of the 1930s to deal with soil erosion and water development for agricultural purposes (Gilson 2013)) are estimated to have once covered $1.9 \mathrm{M}$ ha, of which $1.0 \mathrm{M}$ ha was viewed as native grassland (Bailey et al. 2010). With the divestiture of the land to non-federal entities to be completed by 2017, the conservation role of these lands is in question. The Province of Saskatchewan was the largest recipient of the divested lands and announced the phasing out of the Saskatchewan Pastures Program starting in 2017 (Robinson 2017), thus adding additional angst in regard to how these remnants of native rangelands will be managed. The natural grasslands are known for being hardy and drought resistant and are considered key forage for livestock production (Bailey et al. 2010). The species within these natural grasslands could hold the key for adaptation to predicted climate scenarios. 


\subsection{General Assessments Regarding the Conservation and Utilization of Native Canadian Plant Diversity}

Many authors have identified the relevance of combining conservation and utilization of biological diversity (Heywood 1999b). Others have emphasized the fact that we have only started to explore the potential of wild species for utilization (Balandrin et al. 1985; Small 1995, 1999). The importance not only of living germplasm collections but also of reference collections such as herbaria has been emphasized (Council of Canadian Academics 2010). The vascular plant herbarium maintained by Agriculture and Agri-Food Canada in Ottawa (DAO Herbarium) is a unique source of information and has been instrumental in providing information about the diversity of native Canadian crop wild relatives and for collecting native crop wild relatives in Canada (Agriculture and Agri-Food Canada 2016). The 1.6 million specimens in this herbarium have been assembled since 1886 with an emphasis on weeds, crops, and crop wild relatives (Anstey 1986). The relevance of this collection for identification, localization, and eventual utilization is enormous and its potential by far not realized (Mitrow and Catling 2012; Small 2011). There are only very few herbarium collections in the world having such an emphasis on crop plants, crop wild relatives, and weeds. Digitization of the specimens of this and other herbarium collections in Canada is ongoing and has greatly improved access to these resources. Combining conservation and utilization remains a challenge. Crop wild relative species are obtaining more recognition in fundamental botanical science than in applied agricultural science, but the utilization aspect is often overlooked.

Molecular assessments of diversity in native species enhanced the understanding of diversity and can assist in conservation activities. A molecular research program on native Canadian grass species in association with PGRC has existed since 2002 in collaboration with other scientists in AAFC, National Parks, Environment Canada, the University of Saskatchewan, and Ducks Unlimited to conduct 11 research projects on genetic diversity of more than 14 native grass species (Fu et al. 2005a; Fu and Thompson 2006; Liu et al. 2013; Biligetu et al. 2013). Observations of diversity changes over time and space are helpful to make conservation decisions for such plant material (Ferdinandez et al. 2005; Fu et al. 2005b; Qiu et al. 2009). This advanced knowledge about native grass species contributed to Canadian forage breeding and native grass conservation and restoration. Due to these activities, PGRC acquired more than 100 accessions of these native grass species for PGRC's native grass collection. Cytological studies showed a great divergence between diploid and tetraploid races of small cranberry (Vaccinium oxycoccos L. s.l.) native to Canada (Smith et al. 2015). Chemical evaluations of native Desmodium species at PGRC to assess saponins in the foliage have been conducted and guide users to useful germplasm (Taylor et al. 2009). These accomplishments and the efforts of PGRC and cooperating institutions in collecting germplasm of native Canadian species as shown in Table 2.2 are important to build on for future conservation and utilization 
activities for such germplasm in Canada. The major contributions by the AAFC staff associated with the DAO Herbarium in Ottawa are also a critical building block to ground future work on.

A unique plant native to Canada and the United Sates is wildrice (Zizania palustris, Z. aquatica). In Canada, it is collected from the wild for utilization, while in the United Sates, some breeding has occurred to reduce seed shattering (Small 2014). The seeds are recalcitrant (Aiken et al. 1988), which means they cannot be dried and easily stored in a genebank. In situ conservation is the only feasible strategy for this germplasm, but the natural habitats are in decline. We lack knowledge of the genetic diversity in the species of Zizania native to Canada. A database on Brassicaceae of Canada is available on the Internet site of the Canadian Biodiversity Information Facility (CBIF) and was created because of the relevance of Brassicaceae oilseeds and mustards for the Canadian economy (Warwick et al. 2016). Native berries and small fruits are very important examples of native Canadian species contributing to a major crop (Hancock and Luby 1993; Catling and Cayouette 1994). Some berries are quite rare and only known in the very northern hemisphere, such as Rubus chamaemorus L. (Beaulieu et al. 2013).

Native Canadian Helianthus species are also important (Kantar et al. 2015); of these, H. tuberosus, naturalized in Canada, is well represented at the Canadian genebank (Diederichsen 2010). Many of the Canadian species that are genetic resources also occur in the United Sates, and a coordinated approach between the two countries is beneficial. However, there are many knowledge gaps, and native Canadian species alongside with alien species occurring in Canada should be further studied in their occurrence and potential use. An example is the genus Lactuca L. (Lebeda et al. 2009).

Weeds are well-studied as problems for agriculture in Canada, and their distributions are monitored (CFIA 2008). Darbyshire (2003) provided a comprehensive list of 872 weed species for Canadian agriculture. Many of these weed species were introduced, and some are cultivated plants in other parts of the world, such as Fagopyrum esculentum Moench and F. tataricum (L. Gaertn.). The great importance of weeds as genetic resources is frequently overlooked (Hammer et al. 1997). Again, exceptions exist, such as the recognition of ruderal and weedy hemp as genetic resources (Small et al. 2003) or the recent activities in cow cockle (Willenborg and Johnson 2013). Possibly, weeds are particularly in need of ex situ conservation. They are adapted to cultivated habitats and pressed hard to survive in modern agriculture, where those surviving may eventually all develop herbicide tolerances.

There is no coherent picture when it comes to the study, conservation, and utilization of native and naturalized Canadian plant species for food and agriculture. The size of the country, resulting in great distances among scientific and research institutions, and the fact that the agricultural areas are very concentrated in a few regions are contributing factors to this. But also in strictly botanical issues, incoherence can be observed. For example, for all of Canada, 196 plant species are 
listed with a conservation status "of concern" (COSEWIC 2017). However, an assessment for the province of Québec reports a total of 409 vascular plant species as being of concern for this province alone (Tardif et al. 2016). The potential residing in native Canadian plants is enormous, and there are good reasons to explore in particular Canada's native fruit, forages, and rangeland species. Reclamation projects and forestry are the most advanced in the use of native Canadian plant species.

\subsection{Conclusions, Challenges, and Opportunities to Conserve Native Canadian Plant Genetic Resources}

Native Canadian plants include species used for food, forages, medicinals, ornamentals, forestry, or spiritual reasons. Many are used or have potential for multiple purposes, and there is overlap with species that are crop wild relatives. Many of these species are relevant genetic resources for food and agriculture. Some native or naturalized weed species have potential for utilization, and some are threatened by extinction and are subject to genetic changes due to the industrialization of agriculture. Very few Canadian plant species are likely to become significant agriculturally. Identifying the species with the most potential, researching them, and ensuring the conservation of their genetic diversity are the first step necessary from a genetic resources viewpoint. Canada needs a better understanding not only of the native plant genetic resources that are relevant to the Canadian agricultural sector but also of those that are important from a global perspective. International cooperation in this area will be beneficial since it will spread the burden of expensive ex situ conservation and help share experience in the in situ and on-farm conservation. For example, many of the berry crops in Canada are also relevant in Scandinavia, Russia, and the United States.

We still lack knowledge of phenotypic and genetic properties relevant to utilization of many native Canadian species, although Davidson (1995) provided a baseline for Canada. Due to urbanization and environmental change, we may lose diversity in natural habitats that hold options for the Canadian agricultural sector. In the dominating industrialized agricultural ecosystems, selection pressure is influencing the species and genetic diversity at an accelerating rate. Collections of living germplasm of native species have been assembled at Plant Gene Resources of Canada (PGRC), and research activities have been initiated. Some of these collections are in poor condition and need regeneration.

PGRC should play a role in making decisions when in situ monitoring of native diversity is sufficient and when expensive ex situ conservation at PGRC is not warranted or simply not feasible. Genebanks do not need to preserve all diversity of crop wild relatives and indeed lack the capacity to do so. Priorities for ex situ conservations need to be set based on a strategic and pragmatic approach. The complementarity of in situ and ex situ conservation needs to be established. In many cases, 
monitoring of native populations of crop wild relatives is preferable to ex situ conservation. The latter should only be the last resort to protect a wild species or a certain ecotype of a wild species from extinction. Despite the facilitated access for users when properly preserved in genebanks, the evolutionary implications of ex situ vs. in situ conservation are particularly important in wild species, and protection of natural habitats is more effective for wild species than ex situ conservation. For some obligatory weeds that cannot survive as wild plants, ex situ conservation may be appropriate. It is important to build on the efforts made by PGRC in the past when the program on native Canadian diversity was more active, which was a result of the first response by the Canadian government and AAFC to the CBD in the 1990s.

Hammer (2003) suggested the concept of the "integrated genebank" which would take part in all areas on conservation and utilization of genetic resources. Possibly, genebanks need to be more active, and in fact a concept of an "integrating genebank" needs to be implemented. Such a proactive genebank in the spirit of the International Treaty on Plant Genetic Resources for Food and Agriculture was also outlined by Louwaars (2012). It is desirable to establish more case studies demonstrating diversity of native Canadian species that are crop wild relatives, have potential, or are wild utilized species. The assumption is that many options are not yet explored. Future collecting of herbarium specimens and germplasm would benefit from coordination. It seems appropriate that Agriculture and Agri-Food Canada takes the lead in this area. Such initiative relates to commitments Canada made in international agreements including the CBD and presently under discussion by the Commission on Genetic Resources for Food and Agriculture of the United Nations (FAO 2016c) which suggested developing national strategies for conservation and utilization of crop wild relatives. PGRC should intensify interactions with indigenous Canadian people to support the conservation and utilization of the native Canadian diversity they have utilized for many centuries. Also, it will be important to enhance awareness for biodiversity-related issues not in an abstracts or theoretical way, but by showing and communicating how every citizen can impact the diversity that will be available for the future.

\subsection{Conclusions}

- For economic reasons and from a conservation perspective, there is an urgent need to develop a revised and rigorous Canadian national strategy for conservation and utilization of native Canadian plant diversity that is of relevance to the Canadian agricultural sector. Such a strategy should be developed in coordination among several national stakeholders and with other countries.

- The actual and potential benefits of native Canadian plant diversity to agriculture and for other uses need to be better understood and documented. 
- Enhanced cooperation of Agriculture and Agri-Food Canada with Environment and Climate Change Canada, provincial partners, botanical gardens, First Nations groups, plant breeders, universities, and non-governmental organizations would be beneficial.

- Investing in a strategic and integrative approach and building on the complementarity between in situ and ex situ conservation will secure opportunities for agriculture and benefit all stakeholders.

Acknowledgments The authors are very grateful for supportive discussion and helpful comments by colleagues from Agriculture and Agri-Food Canada: M. Carter, J. Cayouette, B. Gjetvaj, R.K. Gugel, Y.-B. Fu, D.D. Kessler, B. Kitz, K.W. Richards, G.W. Peterson, E. Small, and T.W. Smith.

\section{References}

Agriculture and Agri-Food Canada (1997a) Biodiversity Initiatives, Agriculture and Agri-Food Canada, implementing the Canadian biodiversity strategy, Ottawa, 66 p AAFC.

Agriculture and Agri-Food Canada (1997b) Biodiversity initiatives, Canadian agricultural producers, implementing the Canadian biodiversity strategy. AAFC, Ottawa, $33 \mathrm{p}$

Agriculture and Agri-Food Canada (2016) The agriculture and agri-food Canada collection of vascular plants. http://www.agr.gc.ca/eng/science-and-innovation/research-centres/ontario/ ottawa-research-and-development-centre/the-agriculture-and-agri-food-canada-collection-ofvascular-plants/?id=1251393521021. Accessed 08 June 2017

Agriculture and Agri-Food Canada (2017) Workshop report, Conservation and development of ancestral/indigenous plant genetic resources: Challenges, tools and [perspectives, sharing the Canadian, Mexican and American experiences. 10-11 May 2016, Laval university, Québec City, $60 \mathrm{p}$

Aiken SG, Lee PF, Punter D, Stewart JM (1988) Wild rice in Canada. NC Press, Toronto, $130 \mathrm{p}$

Anonymous (2014) Canadas 5th national report to the Convention on Biological Diversity. https:// www.cbd.int/doc/world/ca/ca-nr-05-en.pdf. Accessed 08 June 2017

Anstey TH (1986) One hundred harvests, research branch agriculture Canada 1886-1986. Agriculture Canada, Ottawa, $432 \mathrm{p}$

Arnason TR, Hebda JR, Johns T (1981) Use of plants for food and medicine by native peoples of eastern Canada. Can J Bot 59:2189-2325

Asselin A, Cayouette J, Mathieu J (2014) Tome 1, Curieuses histoires de plantes du Canada, 1000 1670. Les editions du Septentrion, Québec, 288 p

Asselin A, Cayouette J, Mathieu J (2015) Tome 2, Curieuses histoires de plantes du Canada, 1670 1760. Les editions du Septentrion, Québec, $328 \mathrm{p}$

Asselin A, Cayouette J, Mathieu J (2017) Tome 3, Curieuses histoires de plantes du Canada, 17601867. Les editions du Septentrion, Québec, 309 p

Aurora Institute (2016) NWT Seed Project. http://nwtresearch.com/research-projects/agriculture/ nwt-seed-project. Accessed 08 June 2017

Bailey A, McCartney D, Schellenberg MP (2010) Management of Canadian Prairie Rangeland. Government of Canada, $75 \mathrm{p}$

Balandrin MF, Klocke JA, Wurtele ES, Bollinger WH (1985) Natural plant chemicals: sources of industrial and medicinal materials. Science 228:1154-1160 
Baum BR, Rajhathy T, Thomas H (1972) Notes on the habitat and distribution of Avena species in the Mediterranean and Middle East. Can J Bot 50:1385-1397

Beaulieu J, Otrysko B, Lapointe L (2013) Note sur l'histoire de la chicouté (Rubus chamaemorus L). Le Naturaliste Canadien 125:17-21

Beckie HJ, Francis A, Hall LM (2012) The biology of Canadian weeds. 27. Avena fatua L. (updated). Can J Plant Sci 92:1329-1357

Beckie HJ, Lorzinsky C, Shiriff S, Brenzil A (2013) Herbicide-resistant weeds in the Canadian prairies: 2007-2011. Weed Technol 27:171-183

BGCI (2016) North American botanic garden strategy for plant conservation 2016-2020. http:// northamericanplants.org/. Accessed 08 June 2017

Biligetu B, Schellenberg MP, Fu YB (2013) Genetic diversity of side-oats grama [Bouteloua curtipendula (Michx.) Torr.] populations as revealed by AFLP markers. Can J Plant Sci 93:1105-1114

Bors B (2009) Breeding of Lonicera caerulea L. for Saskatchewan and Canada. In: Russian Academy of Agricultural Sciences (RASCHN) I.V. Michurin All-Russian Scientific Research Institute for Horticulture (ed.) Proceedings of conference "Development and perspectives for blue honeysuckle" 23 March-23 April 2009, Michurinsk, pp. 88-97. Available at: www. lonicera-conference.narod.ru/articles/Bors.pdf

Brouillet L, Coursol F, Meades SJ, Favreau M, Anions M, Bélisle P, Desmet P (2010) VASCAN, the database of vascular plants of Canada http://data.canadensys.net/vascan/about. Accessed 08 June 2017

Canadian Biosphere Reserves Association (2017) http://www.biospherecanada.ca/. Accessed 08 June 2017

Canadian Food Inspection Agency (2008) Invasive alien plants in Canada, technical report. CFIA, Ottawa, 72 pp. Also available online: http://epe.lac-bac.gc.ca/100/206/301/cfiaacia/2011-09-21/www.inspection.gc.ca/english/plaveg/invenv/techrpt/techrese.shtml\#toc20. Accessed July 7, 2018

Carr PM (1993) Potential of fanweed and other weeds as novel industrial oilseed crops. In: Janick J, Simon JE (eds) New crops. Wiley, New York, pp 384-388

Castañeda-Álvarez NP, Khoury CK, Achicanoy HA, Bernau V, Dempewolf H, Eastwood RJ, Guarino L, Harker RH, Jarvis A, Maxted N, Müller JV, Ramirez-Villegas J, Sosa CC, Struik PC, Vincent H, Toll J (2016) Global conservation priorities for crop wild relatives. Nat Plants 2:16022

Catling PM, Cayouette J (1994) Occurrence, origin and status of native germplasm in the Gaspé Peninsula of Québec, with special reference to small fruits. FAO/IPGRI Plant Gen Res Newsletter 100:1-8

Catling P, Porebski S (1998) Rare wild plants of potential or current economic importance in Canada - a list of priorities. Can J Plant Sci 78:653-658

Cayouette J, Fillion N, Coulman B, Michaud R (1997) New opportunities for native perennial bromegrasses. In: Acharya SN (ed) Summary of 1997 Western Forage-Beef Network meeting. AAFC Lethbridge Research Centre, pp 4-5

CBD (2016a) Aichi biodiversity targets. https://www.cbd.int/sp/targets/. Accessed 08 June 2017

CBD (2016b) Canada - National Focal Points https://www.cbd.int/countries/nfp/?country=ca. Accessed 08 June 2017

COSEWIC (2017) Committee on the Status of Endangered Wildlife in Canada. http://www.cosewic.gc.ca/default.asp?lang=en\&n=75113416-1. Accessed 08 June 2017

Council of Canadian Academics (2010) Canadian taxonomy: exploring biodiversity, creating opportunity, the expert panel on biodiversity science. Council of Canadian Academics, Ottawa

Crop Wild Relatives and Climate Change (2013) Interactive map. Online resource. www.cwrdiversity.org/distribution-map/. Accessed 08 June 2017

Darbyshire SJ (2003) Inventory of Canadian agricultural weeds (electronic resources), Her Majesty the Queen in Right of Canada, represented by the Minister of Public Works and Government 
Services. http://publications.gc.ca/site/archivee-archived.html?url=http://publications.gc.ca/ Collection/A42-100-2003E.pdf. Accessed 08 June 2017

Davidson CG (1995) Canadian wild plant germplasm of economic significance. Can J Plant Sci 75:23-32

Diederichsen A (2010) Phenotypic diversity of Jerusalem artichoke (Helianthus tuberosus L.) germplasm preserved by the Canadian genebank. Helia 33:1-15

Diederichsen A (2016) Changes in utilization of the oat genepool preserved by Plant Gene Resources of Canada. In: Abstracts of oral and poster presentations, 10th international oat conference, St. Petersburg, Russia 11-15 July 2016

Dorn KM, Fankhauser JD, Donald L, Wyse DL, Marks MD (2015) A draft genome of field pennycress (Thlaspi arvense) provides tools for the domestication of a new winter biofuel crop. DNA Res 22:121-131

Environment and Climate Change Canada (2016a) Canadian Environmental Sustainability Indicators - Protected Areas, by Ecological Region. www.ec.gc.ca/indicateurs-indicators. Accessed 08 June 2017

Environment and Climate Change Canada (2016b) An invasive alien species strategy for Canada September (2004). http://publications.gc.ca/site/archivee-archived.html?url=http://publications.gc.ca/collections/collection_2014/ec/CW66-394-2004-eng.pdf. Accessed 08 June 2017

Environment and Climate Change Canada (2016c) Canada's protected areas. https://www.ec.gc. ca/indicateurs-indicators/default.asp?lang=en\&n=478A1D3D-1. Accessed 08 June 2017

FAO (2016a) AGP - National Focal Points. http://www.fao.org/agriculture/crops/thematicsitemap/theme/seeds-pgr/gpa/national-focal-points/en/. Accessed 08 June 2017

FAO (2016b) National Focal Points of the International Treaty. http://www.planttreaty.org/nfp

FAO (2016c) Second global plan of action for plant genetic resources for food and agriculture http://www.fao.org/agriculture/crops/core-themes/theme/seeds-pgr/gpa/en/. Accessed 08 June 2017

Federal, provincial and territorial working group on biodiversity (2016) biodivcanada.ca. http:// www.biodivcanada.ca/default.asp?lang=En\&n=6D6EAF77-1. Accessed 08 June 2017

Ferdinandez YSN, Coulman B, Fu YB (2005) Detecting genetic changes over seed increases in an awned slender wheatgrass population using AFLP markers. Crop Sci 45:1064-1068

Fofana B, Sanderson K (2015) AAC Sylvia-Arlene rose for rosehip production. Can J Plant Sci 95:609-613

Fraleigh B, Harvey BL (2011) Chapter 8 The North American group, globalization that works. In: Frison C, López F, Esquinas-Alcázar JT (eds) Plant genetic resources and food security: stakeholder perspectives on the international treaty on plant genetic resources for food and agriculture. Earthscan, London, pp 109-119

Fu YB, Coulman BE, YSN F, Cayouette J, Peterson PM (2005a) Genetic diversity of fringed brome (Bromus ciliatus) as determined by amplified fragment length polymorphism. Can J Bot $83: 1322-1328$

Fu YB, Thompson D (2006) Genetic diversity of bluebunch wheatgrass (Pseudoroegneria spicata) in the Thompson River valley of British Columbia. Can J Bot 84:1122-1128

Fu YB, Thompson D, Wilms W, Mackay M (2005b) Long-term grazing effects on genetic variability in mountain rough fescue. Rangeland Ecol Manag 58:637-642

Gilson JC (2013) Prairie farm rehabilitation administration. The Canadian Encyclopedia. http:// www.thecanadianencyclopedia.ca/en/article/prairie-farm-rehabilitation-administration/. Accessed 08 June 2017

Goering KJ, Eslick RF, Watson CA, Keng J (1966) Utilization and agronomic studies of cow cockle (Saponaria vaccaria). Econ Bot 1:429-433

du Québec G (1996a) Convention on biological diversity. Québec's implementation strategy. Environnement et faune, Québec, p 114

du Québec G (1996b) Québec biodiversity action plan. Environnement et faune, Québec, p 63 
Gros-Louis M, Gariépy SG (2013) Aboriginal agriculture and Agri-food in Québec, status report and considerations for developing a knowledge and technology transfer strategy. Science and Technology Branch Agriculture and Agri-Food Canada, Québec, p 40

Hammer K (2003) A paradigm shift in the discipline of plant genetic resources. Genet Resour Crop Ev 50:3-10

Hammer K, Gladis T, Diederichsen A (1997) Weeds as genetic resources. Plant Genetic Resources Newsletter 111:33-39

Hancock JF, Luby JJ (1993) Genetic resources at our doorstep: the wild strawberries. Bioscience 43:141-147

Harlan JR, De Wet JMJ (1971) Toward a rational classification of cultivated plants. Taxon 20:509-517

Harvey BL, Fraleigh B (1995) Impacts on Canadian agriculture of the convention on biological diversity. Can J Plant Sci 75:17-21

Heywood V (1999a) Use and potential of wild plants in farm households. FAO, Rome, $113 \mathrm{p}$

Heywood V (1999b) Trends in agricultural biodiversity. In: Janick J (ed) Perspectives on new crops and new uses. ASHS Press, Alexandria, VA, pp 2-14

Jefferson PG, Iwaasa AD, Schellenberg MP, McLeod JG (2005) Re-evaluation of seeding native species for forage/beef production on the semiarid prairie of western Canada. Prairie Forum 30:85-106

Jin L, Wang Y, Iwaasa AD, Xu Z, Li Y, Schellenberg MP, Liu XL, McAllister TA, Stanford K (2015) Purple prairie clover (Dalea purpurea vent.) reduces fecal shedding of Escherichia coli in pastured cattle. J Food Prot 78:1434-1441

Kantar MB, Sosa C, Khoury CK, Castañeda-Álvarez NP, Achicanoy HA, Bernau V, Kane NC, Marek L, Seiler G, Rieseberg LH (2015) Ecogeography and utility to plant breeding of the crop wild relatives of sunflower (Helianthus annuus L.). Front Plant Sci 6:841 http://journal. frontiersin.org/article/10.3389/fpls.2015.00841/full. Accessed June 08, 2017

Kerneis S, Swift LH, Lewis CW, Bruyere C, Oumata N, Colas P, Ruchaud S, Bain J, Golsteyn RM (2015) Natural product extracts of the Canadian prairie plant, Thermopsis rhombifolia, have anti-cancer activity in phenotypic cell-based assays. Nat Prod Res 2015:1026-1034

Lee G (2017) Saskatchewan wildflowers. http://www.saskwildflower.ca/native-plant-photos-copyright.html

Lebeda A, Doležalová I, Křistkova E, Kitner M, Petrželova I, Mislerová B, Novotná A (2009) Wild Lactuca germplasm for lettuce breeding: current status, gaps and challenges. Euphytica 170:15-34

Liu Y, Fu YB, Coulman BE (2013) Evaluating genetic variation and relationships among Puccinellia nuttalliana populations using amplified fragment length polymorphism markers. Can J Plant Sci 93:1097-1104

Louwaars NP (2012) Lesson 4: options and examples for implementation of articles 5 and 6 from a user's perspective. In: Mink P (ed) The international treaty on plant genetic resources for food and agriculture, conservation and sustainable use under the international treaty, pp 105-147

Marles RJ, Clavelle C, Monteleone L, Tays N, Burns D (2000) Aboriginal plant use in Canada's northwest boreal Forest. UBC Press, Vancouver, $368 \mathrm{p}$

Martin S, Sauder CA, James T, Cheung KW, Razeq FM, Kron P, Hall L (2015) Sexual hybridization between Capsella bursa-pastoris (L.) Medik (ㅇ) and Camelina sativa (L.) Crantz (đ) (Brassicaceae). Plant Breed 134:212-220

May KW, Wark B, Coulman B (1997) Ecovar development on the northern great plains of North America. Proceeding International Grassland Congress 1997, ID 1-89. http://www.internationalgrasslands.org/publications/1997. Accessed 08 June 2017

Mazza G, Biliaderis CG, Przybylski R, Oomah BD (1992) Compositional and morphological characteristics of cow cockle (Saponaria vaccaria) seed, a potential alternative crop. J Agric Food Chem 40:1520-1523

Minister of Justice (2016a) Plant Protection Act (S.C. 1990, c. 22) http://laws-lois.justice.gc.ca/ eng/acts/p-14.8/. Accessed 08 June 2017 
Minister of Justice (2016b) Seeds Act (R.S.C., 1985, c. S-8) http://laws-lois.justice.gc.ca/eng/ acts/s-8/. Accessed 08 June 2017

Minister of Justice (2016c) Species at Risk Act (S.C. 2002, c. 29) http://laws-lois.justice.gc.ca/eng/ acts/S-15.3/page-2.html\#h-4. Accessed 08 June 2017

Minister of Justice (2016d) Plant Breeders' Rights Act (S.C. 1990, c. 20) http://laws-lois.justice. gc.ca/eng/acts/P-14.6/index.html. Accessed 08 June 2017

Minister of Supply and Services Canada (1995) Canadian biodiversity strategy. Canada's response to the convention on biological diversity. Minister of Supply and Services Canada, Ottawa, p 80

Mitrow G, Catling PM (2012) Evaluation of a collections network as a source of information on economically important plants. The Society for the Preservation of Natural History Collections, Collection Forum 26:70-87

Natural Resources Canada (2017) Forest classification. http://www.nrcan.gc.ca/forests/measuringreporting/classification/13179. Accessed 08 June 2017

Neufeld C (2010) Assessment of native plant materials industry in western Canada and the northern United States - results from providers and users of native plant materials. Native Plant Society of Saskatchewan. Saskatoon, SK p 96

North American Native Plant Society (2016) Native plant societies. http://www.nanps.org/index. php/resources/native-plant-societies. Accessed 08 June 2017

Patzak J, Nesvaddba V, Krofta K, Henychova A, Marzoev AI, Richards K (2010) Evaluation of genetic variability of wild hops (Humulus lupulus L.) in Canada and the Caucasus region by chemical and molecular methods. Genome 53:545-557

Pistorius R (1997) Scientists, plants and politics, a history of the plant genetic resources movement. International Plant Genetic Resources Institute, Rome, p 134

PGRC (2016) Plant Gene Resources of Canada. http://pgrc3.agr.gc.ca/index_e.html. Accessed 08 June 2017

Qiu J, Fu YB, Bai Y, Wilmshurst JF (2009) Genetic variation in remnant Festuca hallii populations is weakly differentiated but geographically associated across the Canadian Prairie. Plant Species Biol 24:156-168

Reynolds AG, Fisher KH, Jamieson A (2015) Grapevine breeding in Canada. In: Reynolds AG (ed) Grapevine breeding programs for the wine industry. Elsevier, Cambridge, pp 311-344

Richards KW (2006) Climate change scenarios in Canada and the role of plant genetic resources. In: Veteläinen M, Helgadóttir Á, Weibull J. 2007. Climatic change and genetic resources in northern Europe. Report of a Workshop, 18-19 September 2006, Rovaniemi, Finland. Bioversity International, Rome, Italy, p 20-31

Richer C, Lafond C, Davidson C (2007) "Félix Leclerc" Canadian artist rose. Hortscience 42:1299-1300

Robinson A (2017) Saskatoon pastures program axed in provincial budget. Regina Leader Post, March 26, 2017. http://leaderpost.com/business/agriculture/sask-pastures-program-axed-inprovincial-budget. Accessed 08 June 2017

Schellenberg MP (2005) Comparison of production and nutritional value of two seed sources of winterfat. PhD Thesis. University of Saskatchewan, p 182

Séguin-Swartz G, Nettelton J, Sauder C, Warwick SI, Gugel RK (2013) Hybridization between Camelina sativa (L.) Crantz (false flax) and North American Camelina species. Plant Breed 132:390-396

Small E (1995) Crop diversification in Canada with particular reference to genetic resources. Can J Plant Sci 75:33-43

Small E (1999) New crops for Canadian agriculture. In: Janick J (ed) Perspectives on new crops and new uses. ASHS Press, Alexandria, VA, pp 15-52

Small E (2011) Alfalfa and relatives: evolution and classification of Medicago. CABI, Wallingford, p 727 
Small E (2014) North American cornucopia, top 100 indigenous food plants. Taylor and Francis Group, Boca Raton, 743 p

Small E, Cayouette J (2016) 50. Sedges - the key sustainable resources for Arctic biodiversity. Biodiversity 17:60-69. https://doi.org/10.1080/14888386.2016.1164624 Accessed 08 June 2017

Small E, Pocock T, Cavers PB (2003) The biology of Canadian weeds. 119. Cannabis sativa L. Can J Plant Sci 83:217-237

Small E, Cayouette J, Catling PM, Brookes B (1995) An opinion survey of priorities for plant systematic and phytogeography in Canada. Bulletin 28:19-22

Smith T, Walinga C, Wang S, Kron P, Suda J, Zalapa J (2015) Evaluating the relationship between diploid and tetraploid Vaccinium oxycoccos (Ericaceae) in eastern Canada. Botany 93:623-636

St-Pierre RG (1992) The development of native fruit species as horticultural crops in Saskatchewan. Hortscience 28:866-947

Canada S (2014) Study: agriculture in Canada. The Daily, Thursday, November 13:2014 http:// www.statcan.gc.ca/daily-quotidien/141113/dq141113a-eng.htm. Accessed 08 June 2017

Tardif B, Tremblay B, Jolicoeur G, Labrecque J (2016) Les plantes vasculaires en situation précaire au Québec. Centre de données sur le patrimoine naturel du Québec (CDPNQ). Gouvernement du Québec, ministère du Développement durable, de l'Environnement et de la Lutte contre les changements climatiques (MDDELCC), Direction de l'expertise en biodiversité, Québec, p 420

Taylor WG, Sutherland DH, Richards KW (2009) Soyasaponins and related glycosides of Desmodium canadense and Desmodium illinoense. The Open Natural Products Journal 2:59-67

Turner NJ (1981) A gift for the taking; the untapped potential of some food plants of North American Native People. Can J Bot 59:2331-2357

Kuhnlein HV, Turner NJ (1991) Traditional plant foods of Canadian indigenous peoples: nutrition, botany, and use. Gordon and Breach, Philadelphia, $633 \mathrm{p}$

University of Saskatchewan (2016) Prairies Fruit Genebank. http://www.fruit.usask.ca/pfg_index. html. Accessed 08 June 2017

UPOV (2016) Texts of the acts of the UPOV Convention http://www.upov.int/upovlex/en/acts. html. Accessed 08 June 2017

Van Raamsdonk LWD, Van der Maesen LJG (1996) Crop-weed complexes: the complex relationship between crop plants and their wild relatives. Acta Bot Neerl 45:135-155

Vavilov NI (1926) Studies on the origin of cultivated plants. Bulletin of Applied Botany 16:3-248

Warwick SI, Francis A, Mulligan GA (2016) Brassicaceae of Canada. http://www.cbif.gc.ca/eng/ species-bank/brassicaceae-of-canada/?id=1370403267260. Accessed 08 June 2017

Willenborg JC, Johnson EN (2013) Influence of seeding date and seeding rate on cow cockle, a new medicinal and industrial crop. Ind Crop Prod 49:554-560

Open Access This chapter is licensed under the terms of the Creative Commons Attribution 4.0 International License (http://creativecommons.org/licenses/by/4.0/), which permits use, sharing, adaptation, distribution and reproduction in any medium or format, as long as you give appropriate credit to the original author(s) and the source, provide a link to the Creative Commons license and indicate if changes were made.

The images or other third party material in this chapter are included in the chapter's Creative Commons license, unless indicated otherwise in a credit line to the material. If material is not included in the chapter's Creative Commons license and your intended use is not permitted by statutory regulation or exceeds the permitted use, you will need to obtain permission directly from the copyright holder.

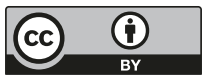

